\title{
Resource endowment and opportunity-cost effects along the stages of entrepreneurship
}

by Tomasz Mickiewicz, Frederick Nyakudya, Nicholas Theodorakopoulos, Mark Hart (Aston University, Birmingham, UK)

\begin{abstract}
In this paper, the start-up process is split conceptually into four stages: considering entrepreneurship, intending to start a new business in the next three years, nascent entrepreneurship, and owning-managing a newly established business. We investigate the determinants of all of these jointly, using a multinomial logit model; it allows for the effects of resources and capabilities to vary across these stages. We employ the Global Entrepreneurship Monitor database for the years 2006 to 2009, containing 8,269 usable observations from respondents drawn from the Lower Layer Super Output Areas in the East Midlands (UK) so that individual observations are linked to space. Our results show that the role of education, experience, and availability of 'entrepreneurial capital' in the local neighbourhood varies along the different stages of the entrepreneurial process. In the early stages the negative (opportunity cost) effect of resources endowment dominates, yet it tends to reverse in the advanced stages, where the positive effect of resources becomes stronger.
\end{abstract}

Keywords Entrepreneurship · GEM - Stages of entrepreneurship · Resources · Opportunity cost $\cdot$ Entrepreneurial capital

JEL Classifications $\mathrm{J} 23 \cdot \mathrm{J} 24 \cdot \mathrm{L} 26 \cdot \mathrm{R} 12$ 


\section{Introduction}

Creation of new firms is considered to be important, both during periods of economic downturn, and in times of prosperity. New firms may be a potential source of economic growth, innovation and employment opportunities, and put competitive pressure on incumbent firms that enhances efficiency and favours consumers (e.g. Aldrich 1999; Beck et al. 2005; Carree and Thurik 2006; Brixy, 2014). Moreover, engaging in entrepreneurial activity is seen as a way of advancing socially, since upward social mobility is one of the main consequences of entrepreneurial success (e.g. Blanden et al. 2005; Minniti and Lévesque 2008; Frankish et al., 2014). Hence, promotion of business start-ups has remained a key agenda item for the economic development policy of most of the developed and developing nations (Atherton 2006; Storey 2003). At the same time, in some regions, high rates of new firms' creation may represent clusters of low value added, low dynamism activities (Van Stel and Storey 2004).

Recent evidence from 69 Global Entrepreneurship Monitor (GEM) countries demonstrated that in 2012 about 14.7 percent of the adult population between the age of 18 and 64 years were actively involved in new-business endeavours, while 7.3 percent were owners of newly established businesses (Xavier et al. 2012). Yet, there is a significant variation in the start-up rates between countries (Kelley et al. 2011; Levie and Hart 2011). To illustrate this point within the more advanced economies, adult population involvement in early stage entrepreneurial activity varies markedly from 13 percent in the United States and 10 percent in the UK, to only 4 percent in Italy and Japan (Xavier et al. 2012). Possible factors affecting cross-country differences in entrepreneurial activity have been identified in the literature (e.g. Autio and Acs, 2010; Aidis et al. 2012; Estrin et al., 2013).

As documented by Bergmann and Stephan (2013), a variation in the rate of entrepreneurship is related to a variation in 'transition rate': the share of those who ultimately create new firms, amongst all those who make some first steps to start a business. The issue of "transition" leads to questions on the determinants of the entrepreneurial stages, which have been investigated at country level by Van der Zwan et al. (2010; 2013), and on individual level by Wasdani and Mathew (2014) and Klonek et al. (2015). In contrast, there is a gap in the literature on combined analysis of the role of individual resources, capabilities and opportunity sets versus contextual influences in the different stages of entrepreneurship (Van der Zwan et al. 2010; 2013). Moreover, we argue that the contextual influences are best explored at the local level, yet, to our best knowledge, the stages of entrepreneurship have not been yet investigated in that way. Let us next explain these gaps in more detail; how we propose to explore them defines our contribution.

Firstly, a particular gap in the literature is that while country level studies now distinguish between environmental and individual effects (again, e.g. Autio and Acs, 2010; Estrin et al., 2013), there is not 
much evidence of this approach being applied at the local level, even if it is where context acquires a more tangible meaning. Given that there is significant variation in entrepreneurship rates not only across but also within countries and regions, such an examination of the local level helps us to gain an in-depth understanding of the role of the individual level resource endowments and opportunities sets contrasted with the role of 'entrepreneurial capital' (Audretsch and Keilbach; 2004, 2005) along the different stages of the entrepreneurial process.

Accordingly, the first objective of this study is to examine whether, and to which extent, both the individual level resource endowments and the entrepreneurial resources in the local environment combine to influence an individual's decision to engage in the different stages of the entrepreneurial process. To this effect, we draw on the resource-based theory (RBT) as applied to entrepreneurship (Alvarez and Busenitz 2001; Kor et al., 2007; Foss, 2011).

Second, our contribution is to argue that RBT needs to be supplemented with an opportunity cost perspective that is critical for entrepreneurial decision making. In particular, we posit that opportunity cost considerations prevail in those entrepreneurial decisions made during the early stages of entrepreneurship; in contrast, resource limitations matter in the mature stages. We find a remarkably uniform pattern related to that, across a number of resource categories.

Third, distinguishing carefully between the individual and the environmental factors, we define the local environment in a precise way, relying on the now established UK methodology that identifies Lower Layer Super Output Areas (LSOA) as meaningful spatial units where individuals interact in an economic sense (Anderson 2008). To focus on variation in 'entrepreneurial capital' on this local level and to limit extraneous spatial variation, we chose one region of the UK (East Midlands) which - as will be discussed - is representative of the UK: we assume that at the regional level, other historical and cultural dimensions should remain similar (see also: Anderson et al. 2010; Bosworth and Gray 2012; Campos et al. 2011).

Fourth, we overcome the limitations of previous studies that have investigated the determinants of entrepreneurship through the use of binary choice models (Blanchflower et al. 2001; Grilo and Irigoyen 2006; Vivarelli 2004). The latter do not consider the fact that the creation of a new firm is a process involving a sequence of choices rather than the outcome of a single binary choice. This study distinguishes between four stages of new firm formation, which are referred to as entrepreneurial stages. These stages include two pre start-up (cognitive) stages: considering and intending to start a business in the next three years, and two early stages of new firm formation (behavioural): nascent entrepreneurs and new business owners (see also: Reynolds et al. 2005; Grilo and Thurik 2005; Grilo and Thurik 2006; Vivarelli 2004; Klonek et al., 2015). We examine determinants of the likelihood of being involved in these different entrepreneurial stages, applying multinomial logit estimator on the 
Global Entrepreneurship Monitor (GEM) data (2006-2009) with 8,269 respondents who reside in the LSOA of the East Midlands region.

Fifth, our data allows for simultaneous testing of the effect of resources at both the individual and the local environment level across these different stages. We show that the weighting of individual factors and local 'entrepreneurial capital' tend to change along the entrepreneurial stages, with 'entrepreneurial capital' becoming less important in the more advanced stages. We attribute this to (entrepreneurship specific) social capital playing a more significant role in the early stages, enhancing opportunity-recognition and self-efficacy (Wasdani and Mathew, 2014). By contrast, competition effects start to bite in the more advanced stages of venture creation.

To summarise, while earlier literature has already observed that the determinants of entrepreneurial choices may vary across the different stages of new firm formation (Davidsson 2006; Wasdani and Mathew, 2014; Klonek et al., 2015), we clarify an underlying mechanism and offer a uniform interpretation anchored in the resource based view, enhanced with an opportunity cost perspective and with a distinction between individual and environmental factors.

In the next section we discuss how this theoretical framework may help in explaining why some individuals engage in different stages of the entrepreneurial process while others do not. From this we derive our hypotheses. Then we discuss the context, the database we drew upon, and outline the methodology. We then summarise the results of the multinomial logistic regressions as formal tests of the hypotheses. Finally, we offer a discussion and draw managerial and policy implications.

\section{Theoretical framework and hypotheses}

Resources and capabilities that are rare, valuable, inimitable and non-substitutable cannot be bought or sold on the market freely (Barney 1991; Barney et al. 2001; Peteraf 1993, 2006; Wernerfelt 1984, 2007; Foss, 2011) and, combined with entrepreneurial effort, result in value adding activities. Based on this conceptualisation, the resource-based theory of entrepreneurship (RBT) explains why certain individuals engage in entrepreneurial activities (Alvarez and Busenitz 2001). According to RBT, (potential) entrepreneurs have specific capabilities that facilitate first the recognition of new business opportunities and next the assembling of the appropriate resources that enable the creation of a new firm (Kor et al., 2007). This perspective leads naturally to a focus on the stages of entrepreneurship, where the first stage relates to the search for opportunities, their discovery and recognition: an enterprising effort in the more narrow sense of the word. This early stage also includes the verification of new ideas. After the opportunities are identified and verified, the second stage consists of exploitation: the identified resources are actually combined and applied in the process of 
new venture creation (Kor et al., 2007; Bergmann and Stephan, 2013; Klonek et al., 2015; Wasdani and Mathew, 2014).

Although we adopt this RBT conceptualisation of the entrepreneurial process, we acknowledge the fact that insufficient attention is being paid to the role that opportunity cost considerations play in entrepreneurial decisions. This relates in particular to the early stages of the entrepreneurial process. While Kor et al. (2007) argue that it is the second stage (exploitation of opportunities) where the economising template may be utilised, we posit that economising is already present in the first stage (opportunity evaluation). This is consistent with the perspective adopted by Klonek et al. (2015), who observe that elements of the cost-benefit analysis can be detected at the beginning of the entrepreneurial process. Our contribution however is to stress that the fundamental concept of opportunity cost is a simple heuristic device that enables us to see resources and opportunities as part of one uniform perspective.

Before we utilise this framework to develop our hypotheses, it remains to classify the resources we intend to focus on. Consistent with MacKelvie and Davidsson (2009), we see resources as broadly defined assets that can be utilised in production. In this case these are: finance; education; job market experience (as proxied by being in employment); and access to social capital (as represented by social networks, particularly those specific to entrepreneurship). In turn, capabilities relate to competences that are critical in order to combine and apply resources successfully (proxied by entrepreneurshipspecific knowledge and skills). Based on this, we now turn to formulate hypotheses related to the differentiated impact of both resources and competences on subsequent stages of the entrepreneurial process.

\subsection{Financial capital as a resource for entrepreneurship}

It has been recognised that individuals often use personal and family income and wealth as a source of start-up capital (Fraser 2004; Gartner et al. 2004; Rouse and Jayawarna 2006), even if they can also rely on "bootstrapping" (i.e. "methods used in meeting the needs for resources without relying on long-term external finance") (Jonsson and Lindbergh, 2013; see also: Ebben and Johnson 2006). As the entrepreneurial project unfolds, external finance (typically from a bank) starts to play a more significant role (Jonsson and Lindbergh, 2013).

Some studies have shown that financial capital is important in determining the probability of both becoming an entrepreneur and of entrepreneurial success (see Black et al. 1996; Blanchflower and Oswald 1998 for United Kingdom and; Evans and Leighton 1989; Evans and Jovanovic 1989; HoltzEakin et al. 1994 for United States). Such studies are often based on the theory of financial constraints: individuals with substantial financial capital find it easier to acquire resources such as machinery and 
equipment, and thus are able to start a new business to exploit business opportunities. In advanced economies with well-developed financial systems it is less likely that financial constraints will apply. However, it would appear that even here, entrepreneurs have idiosyncratic knowledge about the market potential of their projects that is difficult to assess by external providers of finance (asymmetric knowledge). This in turn increases the cost of borrowing and/or leads to constraints in financing (Dunn and Holtz-Eakin 2000; Fairlie and Krashinsky 2012). Accordingly, those with lower levels of wealth and household income may not be able to compensate for the lack of external funds with their own financial resources and this then either prevents them from starting a new business or leads to undercapitalisation (MacDonald 1996; Marlow and Carter 2004; Rouse and Kitching 2006).

However, others have challenged the financial constraints interpretation and have demonstrated that access to financial capital is not significantly associated with the probability of becoming an entrepreneur (Davidsson and Honig 2003; Kim et al. 2006; Klyver and Schenkel, 2013). In these studies, it has been shown that an individual weighs his/her engagement in entrepreneurial activity in terms of opportunity cost in relation to his/her present and potential income from employment. That is, an individual's decision to participate in entrepreneurial activity is taken after weighting the possibility for generating additional income from a new business against the present (sustainable) income and against the possibility for increase in future income from present employment. Therefore, individuals with lower levels of income may also find the opportunity cost of entrepreneurship to be low. In the event of the business failing, an individual may find employment which will restore the initial level of income. Even when the short-term projected income from the new business is similar to his/her current income flow, an individual would engage in the start-up process if there is a potential for higher long term income flows ( Fairlie 2004). In contrast, some members of the labour force who are on a higher income, benefit from rents generated from current employment-specific skills (Sørensen, 2000). Therefore, individuals at higher income levels may find the loss of income from their present occupation outweighs the projected benefits from starting a new business.

Consistent with the above, it has been indicated that the majority of people starting new firms have lower levels of income (Aldrich 1999; Fraser 2004; Williams and Williams 2011), and most of them run small scale and home based enterprises (Jayawarna et al. 2011). Thus, while individuals in highly paid jobs can invest more financial resources in the start-up process (Dunn and Holtz-Eakin 2000; Hurst and Lusardi 2004), they may also find entrepreneurial activities to be less appealing.

Both sides of the argument (financial constraints versus opportunity cost considerations) are well understood. We posit however that examining the entrepreneurial process enables us to distinguish between the influence of both factors across the different stages. In particular, we posit that high household income individuals are less likely to exhibit entrepreneurial intentions. On the other hand, 
those with the lowest incomes are likely to drop off in the more advanced stages of the entrepreneurial process due to resource limitations. Drawing on the above discussion, we propose the following hypotheses:

Hypothesis la: Due to the low opportunity cost, individuals with low levels of household income will be more likely to engage in the early stages of entrepreneurial activity (considering entrepreneurship; entrepreneurial intentions) than those with higher levels of household income.

Hypothesis 1b: Due to financial constraints, individuals with low levels of household income will be less likely to engage in the more advanced stages of entrepreneurial activity (nascent entrepreneurship; owner-managers of new firms).

\subsection{Human capital attributes and entrepreneurship}

Human capital is knowledge and skills that increase effectiveness in performing economic activities, and which can be acquired at a cost (Becker 1964). As with any other form of capital, it enhances one's long-term ability to perform in the market and to create value. Not surprisingly, the RBT posits that human capital is a critical resource that entrepreneurs possess, because when new entrepreneurial opportunities appear, individuals with better human capital are more likely to first identify and then exploit them compared with those with lower level of human capital (Alvarez and Busenitz 2001; see also: Estrin et al., 2016). As knowledge and skills are heterogeneously distributed across the adult population, these may be important factors in understanding why some individuals and not others engage in entrepreneurship (Gartner et al. 2004; Estrin et al., 2016). Formal education and work experience are important components of human capital. Both may or may not represent knowledge and skills relevant for the specific tasks related to creating a new firm (Unger et al. 2011). However, evidence suggests that education and work experience are associated with successful transitions into entrepreneurship (Grilo and Thurik 2008; Van der Zwan et al. 2010; Estrin et al., 2016).

The literature provides several arguments on how formal education increases entrepreneurial success, which we may also apply to the pre-start-up stages. Evidence suggests that highly educated people are believed to be better at solving complex problems (Cooper et al. 1994), which increases their capabilities of performing entrepreneurial tasks (Ucbasaran et al. 2008). This relates to an individual's entrepreneurial alertness (Westhead et al. 2005), the likelihood of discovering opportunities that are not visible to other people (Shane 2000, 2003), and an individual's approach, planning, and strategy to exploit these opportunities (Chandler and Hanks 1998; Frese et al. 2007). Moreover, consistent with the argument above, knowledge can help in acquiring other resources, such 
as financial and physical capital (Brush et al. 2001; Bruton et al., 2014), or compensate for the lack of financial resources (Evans and Leighton 1989). Studies that examined the relationship between education and the probability of starting a new firm have reported a positive association between the two (Davidsson and Honig 2003; Grilo and Thurik 2008; Kim et al. 2006; Estrin et al. 2016).

However, individuals attempt to obtain compensation for their investment in human capital such as time and money spent on education (Becker 1964). Therefore, individuals who are highly educated may not choose to become entrepreneurs if entrepreneurship may lead to reduced income as compared to that from employment (Evans and Leighton 1989). Yet, once those with more human capital engage in entrepreneurial activity, they are more likely to succeed (Cassar 2006). The argument here is parallel to the one developed in the previous section with respect to financial resources: human and financial capital may be seen as an income-generating resource over a range of alternative occupational choices, and therefore may play a similar role in subsequent stages of the entrepreneurial process. The opportunity cost of utilising one's own human capital may prevent individuals from considering entrepreneurship and forming entrepreneurial intentions. At the same time however, human capital may help individuals to become nascent entrepreneurs and, in more advanced stages of the entrepreneurial process, to remain successful owner-managers of the new firms.

Thus, individuals with higher levels of education, once becoming entrepreneurs, are more likely to succeed in the advanced stages of entrepreneurship. However, they are also more likely to be attracted to the labour market as potential high-wage employees, and this affects the likelihood of them viewing entrepreneurship negatively in the process's less advanced stages. Thus, we posit the following hypotheses:

Hypothesis 2a: Due to low opportunity cost, individuals with low levels of education will have a significantly higher propensity to consider and intend to become entrepreneurs.

Hypothesis 2b: Due to low human capital endowment, individuals with low levels of education will be less likely to be engaged in the more advanced stages of entrepreneurship (nascent entrepreneurs and owner-managers of new firms).

Parallel to education, the impact of work experience may reverse as we move along the subsequent entrepreneurial stages. A number of studies claim that unemployed individuals are more likely to be engaged in self-employment due to their lack of employment opportunities (Storey 1994; Evans and Leighton 1989). This issue represents an exemplification of the more general 'push motive', defined as negative circumstances, which induce individuals to establish new ventures (Storey 1994). Thus, 
engagement in early stage entrepreneurial activities is likely to be higher for those not in employment: unemployed individuals could be in a hurry to establish their own businesses because they cannot find suitable employment opportunities in the labour market (Evans and Leighton 1989). In contrast, being in employment has a negative impact on early-stage entrepreneurial activities (considering entrepreneurship and entrepreneurial intentions).

However, employment may be associated with skills and access to resources that those out of work do not possess or gradually lose. Even if many of those out of work had been employed previously, their skills are eroded, particularly so when the spells of unemployment are longer. Once more, our argument is parallel to the line of reasoning we developed with respect to finance and education (hypotheses $1 \mathrm{~b}$ and $2 \mathrm{~b}$ ). Those with worse resource endowment (less experience and skills, proxied by lack of current employment) are motivated to consider entrepreneurship as their opportunity cost is lower. However, at the same time, their lack of resources makes them more likely to drop out later on. Therefore, they are relatively less represented in the more advanced stages of the entrepreneurial process. Accordingly, the following hypotheses are proposed:

Hypothesis 3a: Individuals who are currently employed are less likely to engage in the early stages of the entrepreneurial process (considering entrepreneurship and entrepreneurial intentions) than individuals who do not work.

Hypothesis 3b: Individuals who are employed are more likely to be nascent entrepreneurs than individuals who do not work.

While education and experience may form generic resources appropriable for entrepreneurship, more specific skills matter as well (Estrin et al., 2016). In this study, entrepreneurship-specific human capital assets are defined as knowledge and skills that facilitate starting a new firm (Arenius and Minniti 2005). These skills are required to assemble new resources and combine them with resources he/she already possesses, or to reconfigure existing resources (Alvarez and Busenitz 2001). An entrepreneur is characterised by unique knowledge of how to organise ideas and capabilities in order to produce new products and services under uncertain conditions (Alvarez and Barney 2007; Miller 2007). Entrepreneurial experiments tend to be undertaken in conditions where information does not yet exist, therefore it cannot be collected or analysed. Hence for new projects, traditional codified forms of strategic planning may often be harmful or misleading (Alvarez and Barney 2007).

Extant evidence from empirical testing confirms that lower levels of entrepreneurship-specific skills hinder prospective entrepreneurs from starting a new firm (Davidsson 1991). However, again, 
we extend this perspective arguing that the impact of specific skills will vary along the stages of entrepreneurship. These skills will affect positively all the stages, but more so in the advanced phases. The reason for this is that while motivation will be affected positively in all the stages, capacity to deliver will become critical in the phase of implementation. It is, therefore, in the latter stage that the impact of specific entrepreneurial skills will become stronger. Based on the above discussion, we propose the following hypotheses:

Hypothesis 4a: Individuals with higher levels of specific entrepreneurial knowledge and skills will have a significantly higher propensity to consider entrepreneurship and to have entrepreneurial intentions (i.e. to be involved in the earliest stages of the entrepreneurial process).

Hypothesis 4b: Individuals with higher levels of specific entrepreneurial knowledge and skills will be more likely to engage in nascent entrepreneurship. Moreover, this effect will be stronger for nascent entrepreneurs than for those in the earliest stage of the entrepreneurial process.

\subsection{The local context: entrepreneurship capital}

The hypotheses above were concerned with the individual characteristics of potential entrepreneurs. However, the local environment may also have a critical impact on the individual's decision to engage in various stages of entrepreneurship. This local social environment is often considered in the context of social network relationships. Notably, networks provide social capital that may be appropriable for entrepreneurship, i.e. another broadly defined resource (Anderson 2008). The social network approach to understanding the role of social capital in the creation of new firms is based on Granovetter's (1973) seminal work, which made a distinction between strong and weak ties (see also Coleman, (1988). Networks characterised by frequent and repeated homogenous social interactions are labelled 'strong ties' (also see, Son and Lin 2008). If entrepreneurs are connected to others with whom they have little emotional engagement, these heterogeneous relationships are defined as 'weak ties' (Batjargal et al. 2009; Granovetter 1973). Both come with different benefits and may play a different role within the entrepreneurial process. However, weak ties that reach beyond family and close friends may provide individuals with access to wider and more diverse knowledge banks that may prove particularly useful for business activity. This is particularly true if the profile of the local social environment exhibits entrepreneurial traits. It determines the opportunities for individuals to form entrepreneurship-relevant weak ties that in turn help those individuals to enter into entrepreneurship. In particular, entrepreneurship capital is a "specific type of social capital that explicitly generates" the start-up of new firms by making the local environment rich with explicit or implicit knowledge and other 
entrepreneurship-specific resources (Audretsch and Keilbach 2004: 421). Audretch and Keilbach $(2004,2005)$ define a specific type of social capital as the regional milieu of agents that may facilitate or hinder new firm formation and proxy it with the exiting rates of entrepreneurial activity.

This approach assumes that such a milieu creates both role models (motivation) and network opportunities based on weak ties that are conducive to entrepreneurship. Evidence suggests that the weak (bridging) ties are highly correlated to entrepreneurship-relevant information and tangible capital (Carter et al. 2003; Davidsson and Honig 2003; Hughes et al. 2007). Audretsch and Keilbach (2004) point out that regions with a higher density of entrepreneurship (and therefore a higher likelihood of relevant weak ties) facilitate the creation of new innovative firms, leading to agglomeration and persistence effects.

Thus, weak social ties are most useful when they include individuals with knowledge specific to entrepreneurship. The higher the number of business people in the local environment, the more likely it is that the social contacts could produce knowledge valuable to (potential) entrepreneurs. In particular, it can be argued that if an individual has a network relationship with another person, that individual will indirectly also share the knowledge of that other person's (Dubini and Aldrich 1991). In such a scenario, both parties will end up learning what the other party knows, resulting in the flow of information between the individual and the other person's contacts. Therefore, in a local environment dense in entrepreneurial activity, there is more knowledge available to support entrepreneurship. Accordingly, Audretsch and Keilbach (2004) argue that regions with higher levels of entrepreneurship capital facilitate start-ups because there are more conduits for knowledge spillover.

As before, the element we stress in this paper is the linking of this argument to the stages of entrepreneurship. We posit that an individual acquires knowledge and skills relevant to entrepreneurship as he/she moves along the subsequent stages of the process (or up the 'entrepreneurial ladder', applying Van der Zwan et al. (2010) terminology). Therefore, an opportunity to draw from the environment is most critical in the earliest stages of entrepreneurial activitiy. As emphasised by Wasdani and Mathew (2014), discussing one's own ideas with those who are experienced in entrepreneurship enhances opportunity recognition in the initial phase of the entrepreneurial process. Similarly, Klonek et al. (2015) argue that discussion of entrepreneurial ideas and 'sustained talk' play an important role in enhancing the self-efficacy of the potential entrepreneur, which is typically lower in the early stages of the project.

Moreover, in late stages of the entrepreneurial process, i.e. when the entrepreneurial project materialises, these positive environmental effects may to some extent be counterbalanced by the impact of competition. Those who merely intend to start new businesses do not face competition from other 
business owners; those who move on to become owner-managers of new firms do. Based on these arguments we propose the following hypotheses:

Hypothesis 5a: A higher density of established owner-managers of businesses in the local neighbourhood will have a positive effect on an individual's likelihood of considering entrepreneurship and of intending to start a new business (i.e. to be involved in the early stages of the entrepreneurial process).

Hypothesis 5b: A higher density of established owner-managers of businesses in the local neighbourhood will have a positive effect on an individual's likelihood of becoming a nascent entrepreneur and an owner-manager of a new business. However, this positive effect will be weaker as compared with the likelihood of an individual's engaging in the early stages of entrepreneurial activity.

\section{Context}

We now turn to our empirical counterpart and start with the discussion of the local context. The data for this study is drawn from the East Midlands, a region that has little historical precedent but was formed as a result of the activities of geographers and planners in the $20^{\text {th }}$ century; concerns for equal span of administrative control trumped other arguments in the UK administrative divisions for the English regions (Hogwood, 1995).

The region was formally named the North Midlands in 1939 as a civil defence area used by the military for post-World War reconstruction. The region was officially renamed the East Midlands in 1965. It has six counties (Derbyshire, Leicestershire, Lincolnshire, Northamptonshire and Rutland) and a population of approximately 4.6 million, who live in an area measuring 15,606 square kilometres.

The East Midlands economy has been mainly based on manufacturing, retail, wholesale industries, and the service sector characterised as low skill, high employment, and low wage. Thus, East Midlands as a region has been heavily exposed to the decline in the production industries; and this decline became a major source of regional inequality during the past four decades. Yet despite a fall in employment in the manufacturing, retail and wholesale sectors, and the region's sensitivity to UK wide trends, employment in the East Midlands region has been relatively immune to recession shocks experienced during the 1979, 1990 and 2008 recessions. The region has the highest proportion of jobs in manufacturing, and the lowest proportion of jobs in finance amongst UK regions. With a good mix of urban and rural areas, the region has been an average performer on a range of social and economic indicators. This was reinforced by studies that indicated the resilience of East Midland's economy 
during and after the recession (Bosworth and Gray 2012; Campos et al. 2011; Levie and Hart 2010). Campos (2011) indicated that although there was a decline in the rate of employment in 2009, total household income grew at the same rate as most of the UK regions during the 2008/2010 recession. The region has 194,275 businesses with a rate of employment of $71.5 \%$ and an unemployment rate of 7.8\%; the employment rate is marginally higher than that of the UK, West Midlands or London which are $70.6 \%, 68.3 \%$ and $68.9 \%$ respectively (ONS 2013). The median gross earnings in 2012 was $£ 24,798.80$, comparable to the neighbouring West Midlands with $£ 24,403.60$.

Historically, small firms were not a strong characteristic of the UK regions. However, with the economic crises of 1979, 1990 and 2008 and the rise in unemployment, there has been greater interest in entrepreneurship. Being driven by a response to the crises, these rates of new firms' creation may however represent clusters of low value added, low dynamism activities (Van Stel and Storey 2004). At the same time, data shows that the public sector played a major role in job creation between 1998 and 2007 in the UK regions and it was estimated that $57 \%$ of all new jobs were government dependent. While the West Midlands' and North East's dependence of the state accounted for $153 \%$ and $79 \%$ of the job increases respectively, the East Midlands has been less dependent on the state, which only accounted for a $55 \%$ increase in new jobs.

The East Midlands always features in the middle of the table of regional performance. Its performance is similar to that of the UK as a whole. Being not particularly idiosyncratic, it represents a valuable case study for understanding how individual level resource endowments and the subregional environment combine to influence an individual's decision to engage in the different stages of the entrepreneurial process. $34.6 \%$ of the labour force was employed in administration, technical or skilled trade occupations, which is slightly lower than the percentage for the UK as a whole with $35.6 \%$ (ONS 2013). The GEM data also show that between 2007 and 2009 the total entrepreneurial activity (TEA) rate for the region was constant at 5.3\%, which is almost the same as the UK 2007 and 2008 rate, which was 5.5\%, and rose to 5.8\% in 2009 (Levie and Hart 2010), as shown in Table 1.

\section{$\{$ Table 1$\}$}

Among the 12 regions of the UK, East Midlands is ranked sixth in terms of the proportion of entrepreneurs who are engaged in early stage entrepreneurial activity. A similar pattern is revealed in Table 2 where we break the entrepreneurial process into different stages. The East Midlands always features in the middle of regional league tables for the UK. 


\section{Methodology}

We test these hypotheses with two large databases combined: the English Index of Multiple Deprivation (2007 release) database and the 2006 to 2009 GEM East Midlands region databases. The UK GEM database consists of random samples, stratified by region, of the working age (16 to 64 years) population contacted by telephone random dialling techniques by a professional marketing company. The East Midlands sample size varied from 2,296 in 2007 to 2,807 in 2009, resulting in a total of 8,269 usable cases. This data was used to generate indicators of stages of the entrepreneurial process among surveyed individuals. Accordingly, our sample includes (i) individuals with no business ownership intention, (ii) those considering entrepreneurship, and (iii) those intending to start a business within the next three years. Following that, (iv) the nascent entrepreneurship phase includes 'individuals who are actively trying to start a business', according to a number of standardized criteria specified in the GEM questionnaire (Reynolds et al., 2005). Finally in the second version of our estimating model we also include (v) owners of newly established businesses (up to 42 months). However, for the latter model we include a smaller number of explanatory variables: some are excluded due to our concern with simultaneity (endogeneity) issues.

The variables related to our hypotheses include: household income categories (H1a), past experience of being the business angel ( $\mathrm{H} 1 \mathrm{~b})$, highest educational attainment ( $\mathrm{H} 2 \mathrm{a}, \mathrm{H} 2 \mathrm{~b})$, being in employment (H3a, H3b), self-assessed knowledge and skills specific to entrepreneurship (H4a, $\mathrm{H} 4 \mathrm{~b}$ ), and finally, prevalence rate of owner-managers of established businesses more than 42 months old in the local neighbourhood (H5a, H5b). In addition, we include a number of controls at the individual level, as is standard in the empirical literature on aspects of entrepreneurship: age, gender, being an owner-manager of an already existing business, and personally knowing other entrepreneurs.

A number of studies have demonstrated that the local socio-economic environment matters for entrepreneurship (Anderson and Miller 2003; Cooke et al. 2005; Kalantaridis and Bika 2006). Lee et al (2011) showed that in deprived areas with social networks restricted to bonding capital, strong ties do not facilitate access to motivation and material resources. We measure the community's level of socio-economic development using the English Index of Multiple Deprivation (IMD) and its component indicators for 2,732 Lower Layer Super Output Areas (LSOA) communities with an average population of 1,500 people (DCLG 2010). After cleaning the postcodes in the GEM database, we were able to classify each respondent in the East Midlands into their LSOA, by inputting postcode data into the Geo-Convert facility. Then, we ranked each respondent according to their local community's level of socio-economic development (IMD). We then split the sample into ten equal groups according to their rank using the quintile facility in Stata. In addition, we include fixed effects 
related to the higher level territorial units, which are counties, and an indicator variable representing urban versus rural areas (at LSOA level). Table 3 below shows the description of variables used in this study.

$\{$ Table 3$\}$

Correlation coefficients for the variables used in the regressions are presented in Table 4 below. These are not excessively high therefore multicollinearity problems with further analysis are not anticipated.

$\{$ Table 4$\}$

\subsection{Estimation Strategy}

We apply a multinomial logit estimator (MNL) to predict the likelihood that an individual is engaged in any entrepreneurial stage, given his/her resource endowment and capability. MNL is commonly applied for the occupational choice model (Wooldridge 2010), and our research question may be seen as extending the occupational choice mode to include intentions. MNL extends the principles of linear models to give a better treatment of those dependent variables that come in a form of a range of outcomes over the choice set. It is based on weaker assumptions than a corresponding ordered logit model, allowing for different variable coefficients for different outcomes. The model allows for a study of a mixture of continuous and categorical independent variables explaining a set of categorical outcomes, estimating a separate equation for each outcome compared with the reference one; the latter in our case is taken as lack of any entrepreneurial activity or intention (Long and Freese 2003). Maximum likelihood estimations are used to calculate the logit coefficients (Gelman and Hill 2006), which we exponentiate to obtain the odd ratios, to facilitate interpretation. More precisely, we report the multinomial relative risk ratios (RRR) for each stage of the entrepreneurial process. An RRR above one indicates that the risk of the outcome falling in the comparison group, relative to the risk of the outcome falling in the reference group, increases as the variable increases. If the RRR is less than one, it indicates that the risk of the outcome falling in the comparison group relative to the outcome falling in the reference group decreases as the variable increases. The key limitation of the multinomial logit model is in its rather strong assumption that any odd ratio for one choice does not depend on odd ratios for other choices, which follows from independence in disturbances (Greene 2003). This calls for the application of tests of irrelevance of independent alternatives, which we explain below.

We first estimated the model with four options: (i) passive - no entrepreneurial activity, a baseline, reference category; (ii) considering entrepreneurship, (iii) intending to start-up a business, and (iv) 
nascent entrepreneurs. As our explanatory variable, we use those listed in Table (?) above. However, we verified that we could not reject the model assumptions on the basis of Small-Hsiao tests of Independence of Irrelevant Alternatives, which came as highly insignificant for each of the outcomes. In addition, we performed a series of Wald tests for differences in coefficients between all pairs of outcomes. These all came as significant, being at least a level of 1\%, indicating there is no ground for combining any of the alternatives. This is the first of our models presented below in the results section.

For the second model we use one additional option, which is (v) being the owner-manager of a new ('baby') firm, less than 42 months old. Applying this richer model comes at cost, as it creates simultaneity (endogeneity) problems with some of the variables. In particular, the level of household income, personally knowing other entrepreneurs, possessing entrepreneurial skills and being in employment are all affected by being involved in managing a business operation. In addition, we can no longer treat ownership of new business as one of the controls, as that would cause circularity. Accordingly, we dropped all these variables from the model. As before, we verified that the model holds based on the Small-Hsiao tests. Interestingly however, this time we could not reject the hypothesis that the coefficients for 'considering entrepreneurship' and 'intending to start a business' are the same. Accordingly, in our final specification we combined these two. Based on Small-Hsiao tests, the coefficients related to the other outcomes are not affected. Thus, as a result, the second model we report is based again on four, albeit different, outcome categories: (i) passive - no entrepreneurial activity, a baseline, reference category; (ii) considering entrepreneurship or intending to start-up a business, (iii) nascent entrepreneurs, (iv) owner-managers of new businesses (up to 42 months old).

Before presenting the results, some measures for the explanatory power and diagnostics of the models are presented in Tables 5 and 6 below and are discussed in the following section. We also investigated the strength of the relationship among the explanatory variables using the collin command in the Stata package to check for multicollinearity. Multicollinearity may cause inflated standard errors and sensitivity of coefficients to small changes in the set of explanatory variables. Tolerance and variance inflation factor (VIF) are the two common measures of multicollinearity. Our results show that the minimum tolerance is 0.5850 and the highest VIF is 1.85 , which indicates that the relationship among the explanatory variables is weak. Therefore, we can conclude that there is no cause for concern, since there is no variable with a tolerance less than conventional 0.1 or a VIF of 10 or greater. Moreover, any potential impact of multicollinearity on the stability of coefficients is counterbalanced by the large sample size.

While most of our hypotheses relate to individual level variables, H5a and H5b concern the environmental effect of entrepreneurship capital. However, while calculating our standard errors and the related significance levels, we should account for the fact that our observations are interdependent 
within each local community (LSOA). Accordingly, we cluster our standard errors on the LSOA to make them robust. This deals with the issue related to the possibility that individuals residing in the same LSOA are more likely to have similar characteristics, resources and capabilities that differentiate them from those residing in other LSOA. Such correlation, if left unattended, is a violation of one of the classical assumptions of the regression models.

\section{Estimation results: hypotheses testing}

Estimation results of the two models discussed above are presented below. In summarising the results, we concentrate on the variables related to our hypotheses. These represent income level, human capital and the environmental effect of entrepreneurial capital. The relative risk ratios of the maximum likelihood estimations for the two models are presented in Tables 5 and 6. We supplement it by reporting results of additional tests, comparing coefficients across different outcomes and with some visual illustration of the results.

$\{$ Tables 5 and 6$\}$

Based on Model 1, our results indicate that higher levels of household income, above "Up to $£ 11,500 "$ (our lowest, benchmark omitted category), decrease the probability of considering entrepreneurship and of entrepreneurial intentions, confirming H1a (opportunity cost considerations). However, we could not confirm H1b: we did not find that the nascent entrepreneur status is positively related to income (resource constraints considerations). Once we performed additional tests for differences in coefficients across the outcomes, we found differences for most of the categories to be insignificant for the income variable. Overall, we conclude that the lowest income category is uniformly associated with considering entrepreneurship, and intending and being engaged in start-ups (nascent entrepreneurship). It is likely that the pattern is reversed with ownership of young firms, but as discussed, we did not include income in these models due to simultaneity concerns. Moreover, our intuition on the reversal of the effect along the stages of entrepreneurship is established in a more narrow sense: the pattern jointly represented by Hypotheses 1a and $1 \mathrm{~b}$ is actually confirmed for the highest income category, as we will explain below when discussing the magnitude of the effects.

In turn, the results concerning human capital based on educational variables turned out to be sensitive according to which outcome category we relied upon. We had expected that the coefficients on educational variables would change once we moved along the entrepreneurial stages, but what we 
found is that the critical difference is not between considering and intentions on one side, versus startups and new firms on another, but between start-ups and owner-managers of new firms. In particular, for new firms ('baby businesses'), the effect of higher competences dominates, producing a pattern consistent with $\mathrm{H} 2 \mathrm{~b}$. However, once we move one step back to nascent entrepreneurs, this positive effect of education seems still to be counterbalanced by the negative impact of the opportunity cost of education, attenuating the effect, consistent with H2a. Thus, it is less likely that the most educated individuals are involved in starting new companies (nascent entrepreneurs) than that they are owners of new firms. This difference is illustrated by Figures 1 and 2 below, which are based on Model 2 results (in Table 6). The difference between the two outcomes (nascent and young ventures) is significant at 5\% level for education variables. Tentatively, we declare support for both $\mathrm{H} 2 \mathrm{a}$ and $\mathrm{H} 2 \mathrm{~b}$, however with a slight variation as discussed above.

\{Figure 1 and 2)

The argument proposed in Hypothesis $3 \mathrm{a}$ is that individuals who are employed may not choose to be entrepreneurs because entrepreneurship may lead to a reduced income as compared to that obtainable from employment opportunities. The results are consistent with Hypothesis 3a, indicating that being employed reduces the likelihood of both considering and intending entrepreneurship. Moreover, in line with $\mathrm{H} 3 \mathrm{~b}$, the difference in coefficients between intenders and those involved in start-up (nascent entrepreneurs) is statistically significant at $1 \%$ level. As expected, the impact of higher opportunity cost (which prevents individuals from considering and intending to become entrepreneurs) is counterbalanced by capabilities, and once we move to more advanced stages of entrepreneurship the odds ratio changes from below one to above one, now indicating positive impact.

Consistent with our theoretical prediction (H4a), the results show that entrepreneurship-specific skills and knowledge increase the probability of considering and intending to become an entrepreneur, and also to become a nascent entrepreneur. Moreover, consistent with $\mathrm{H} 4 \mathrm{~b}$, the impact of specific skills is much stronger for nascent entrepreneurs; the difference in coefficients between intenders and nascent entrepreneurs is significant at $1 \%$ level.

Based on Hypothesis 5a, we expected that the presence of other entrepreneurs in the neighbourhood is likely to have positive effects on considering entrepreneurship (while controlling for knowing other entrepreneurs individually). This is confirmed for the 'considering entrepreneurship' category at 5\% significance level. However, according to H5b, we argued that once we move along the subsequent stages of the entrepreneurial project, the effect becomes weaker: in environments where density of business activity is high, the negative effect of competition will counterbalance the positive 
effects. Indeed, we can see from Model 1 and Model 2 that the coefficient on business density diminishes and becomes insignificant. However, we cannot formally confirm H5b as the difference in coefficients in adjacent models is not significant.

The above discussion was focused on statistically significant effects from testing our set of hypotheses. We next explore the magnitude of the results. To this effect, we present below the odd ratio plots (also named factor change coefficients), which show by which factor a unit increase in an explanatory variable affects the probability of choosing any of the outcomes (entrepreneurial stages), holding all other variables at their mean value (Gelman and Hill 2006; Long and Freese 2003). The four entrepreneurial stages are labelled as: considering (C), intenders (I), nascent entrepreneurs (N) and 'baby' (new) business owners (B), and these are contrasted with entrepreneurial passivity, i.e. no business creation intentions $(\mathrm{P})$. On the graphs below, the effect of each explanatory variable represents a separate row; negative effects relative to the reference outcome are on the left hand side and positive on the right hand side, and the distance between any pair of outcomes (letters) represents the magnitude of the effects. Any two effects that are not distinguishable by at least $10 \%$ are connected by a line.

We already presented the effects of education in more detail at Figures 1 and 2 above; at Figure 3 (based on Model 1) we now summarize the effects of the categorical explanatory variables related to other hypotheses. Moving up the income categories makes entrepreneurship less likely compared to the lowest income group (omitted). Consistent with what we signalled above, at the highest income category (the head of the household earning over $£ 50 \mathrm{k}$ ), the sequence of entrepreneurial stages becomes clearly separated: being involved in nascent entrepreneurship becoming least likely, followed by considering and intentions, and finally being passive in terms of entrepreneurship. We may conclude that for high income, the opportunity cost effect of entrepreneurial activity dominates the resource endowment effect, and moreover this dominance increases as we proceed along the entrepreneurial stages.

For the next variable, employment, as predicted by H3a, the opportunity cost affects considering and entrepreneurial intentions negatively. However, it is significantly different for nascent entrepreneurs, for whom it becomes counterbalanced by the resource effect, again in line with H3b.

Last but not least, the magnitude of the effects of entrepreneurship-specific skills dominates those of the other variables, and the ordering of the effects is consistent with H4a and H4b: these competences have a positive impact on considering entrepreneurship and on entrepreneurial intentions, and an even stronger effect on the likelihood of being involved in nascent entrepreneurship.

$\{$ Figure 3$\}$ 
In Figures 4 and 5 we illustrate the magnitude of effects for our control variables (based on Model 2). Figure 4 illustrates the effect of age, where we see a clear separation of entrepreneurial stages and a consistent diagonal pattern of all the effects, implying that with age, the entrepreneurial activity gets weaker. The effects of all age categories should be seen as relative to the reference, which is the youngest age group. The likelihood of considering and intending entrepreneurship (C) declines consistently with age. So does the likelihood of being involved in nascent entrepreneurial activity (N), but for the next two groups above the youngest, the odds are higher than one, implying that the likelihood first increases with age, to decline later on in a non-monotonic pattern. The ownership of new ('baby') businesses (B) exhibits a similar logic.

The first row of Figure 5 illustrates the effects of gender that are significant, but of low magnitude. Men are more likely to be engaged in all stages of the entrepreneurial activity, and the effect is strongest for the most advanced stage (owner-managers of young businesses).

Being an owner manager of an established business has a very strong negative effect on the likelihood of considering, intending, and being involved in nascent entrepreneurial activity, which is again consistent with our emphasis on the opportunity cost perspective. However, for the advanced stage of ownership of new firms, the effect is counterbalanced by the positive impact of capabilities, again consistent with our main argument. Being a business angel in the past implies a greater likelihood of being engaged in entrepreneurship, reflecting both possession of/access to resources and capabilities. And finally, for comparison, urban versus rural area has no significant impact.

$\{$ Figure 4 and 5 \}

\subsection{Limitations}

We are aware of some of the limitations of this study that might have influenced the results. The GEM dataset does not contain information on individual income level; therefore, head of household income data has been used, which could imply measurement errors. Moreover, the survey does not convey information that could be used to understand the financial bootstrapping strategies of entrepreneurs, while arguably these can evolve along the stages of entrepreneurial projects (Ebben and Johnson 2006). We may also be omitting important variables such as those related to a more detailed representation of work experience that would help in understanding how individual resource endowments affect the probability of engaging in entrepreneurial activity. Here again, we are limited by the GEM dataset. A doubt can be also raised about the GEM entrepreneurial skills measure, which is self-reported and not based on objective information. Due to the nature of the dataset, we have addressed the probability of 
engaging in any stage of the entrepreneurial process purely from a static point of view, and surely this is inferior to a dynamic analysis, for the same individuals over time.

Finally, and this time not specific to GEM data, another limitation we need to bear in mind is that various types of resources are related. Income and financial resources often correlate with human capital; therefore, the two effects may become confounded and attenuated. In this case, there is potential attenuation bias: it works against our tests.

\section{Discussion and conclusion}

With these caveats in mind, in this paper we argue that the influence of individual resources and capabilities changes as we move along the entrepreneurial stages. In the early stages of the entrepreneurial process, the opportunity cost effect prevails and those individuals with better resource endowment are discouraged from forming entrepreneurial intentions. However, for those who enter entrepreneurship, this effect is reversed. Greater access to resources and capabilities imply that it becomes easier to reach the advanced stages of entrepreneurship. For most of the dimensions we consider, this pattern is confirmed. This has important managerial and policy-making implications.

A better understanding of the correlation between resources, capabilities and entrepreneurial stages enables us to identify where the risk of discontinuity in the process is the highest. For those with low resource endowment, motivation and forming intentions is not a major problem. The main issue becomes how to overcome resource limitations during the more advanced stages and complete the project successfully. This conclusion is in line with Van Stel et al. (2007) who argue that it is the resource-constrained, necessity entrepreneurs, who may benefit more from a policy oriented on overcoming barriers related to a lower level of human capital and financial endowment. In contrast, quality resource endowment demotivates individuals from entering entrepreneurial activity due to the higher opportunity cost. Therefore, here an emphasis on motivation and intentions is critical, so that those with resources become aware of entrepreneurial opportunities.

An important further qualification is that the impacts of generic and entrepreneurship-specific skills differ. The former have an ambiguous effect, as we just sketched, while the latter have a clear positive effect on both intentions and on the successful delivery of the entrepreneurial project. Thus, one way to encourage individuals with quality resource endowment to enter entrepreneurship is simply to complement that endowment with entrepreneurship-specific skills.

Finally, we highlight the role of the local 'entrepreneurial capital' and clarify how this environmental effect changes along the entrepreneurial process. In this, and other cases, distinguishing clearly between the different stages of entrepreneurship enables us to resolve some of the ambiguities 
found in the literature, which we highlighted above. In particular, while a vibrant business environment has an unambiguous positive impact on considering entrepreneurship, this positive effect is not carried over to the further stages of entrepreneurship due to increased competition. Here, we also emphasise that the appropriate choice of what constitutes the local environment matters. Our operationalisation of "local" at the level of economically defined LSOA works well. In contrast, the problem with the analysis of a higher, regional-level variation in entrepreneurship is that the relative positions of the regions tend to change little over time, and this is also why long-term historical variables play a role at the regional level (Fritsch and Storey, 2014). From that point of view, the focus on lower-level economically defined localities may be of more value, and there are more dimensions to explore here beyond our humble effort.

Ultimately, successful new firms need to rely on rare, valuable, inimitable and non-substitutable resources (Barney 1991; Barney et al. 2001; Peteraf 1993, 2006; Wernerfelt 1984, 2007), and we posit this is why in the more advanced stages of the entrepreneurial process, the impact of individual resources and capabilities dominates over the environmental effects. Thus, we stress the role of the individual in entrepreneurship, which brings us back to the core intuitions of entrepreneurship research that we inherited from Schumpeter (1934), Kirzner (1973) and others. Yet, while we emphasise the importance of the individual, we also stress that his/her capabilities and resources are formed in social relations. 


\section{References}

Aidis, R., Estrin, S., and Mickiewicz, T. (2012), 'Size matters: entrepreneurial entry and government', Small Business Economics. 39, 119-139, doi: doi: 10.1007/s11187-010-9299-y.

Aldrich, H. (1999), Organizations evolving (London: Sage ).

Alvarez, S.A. and Busenitz, L. W. (2001), 'The entrepreneurship of resource-based theory', Journal of Management, 27 (6), 755-75, doi: 10.1016/S0149-2063(01)00122-2.

Alvarez, S.A. and Barney, J.B. (2007), 'Discovery and creation: Alternative theories of entrepreneurial action', Strategic Entrepreneurship Journal, 1 (1-2), 11-26, doi: 10.1002/sej.4.

Anderson, A. and Miller, C. J. (2003), '"Class matters": human and social capital in the entrepreneurial process', Journal of Socio-Economics, 32 (1), 17-36, doi: 10.1016/S1053-5357(03)00009-X.

Anderson, A. R., Osseichuk, E., and Illingworth, L. (2010), 'Rural small businesses in turbulent times Impacts of the economic downturn', The International Journal of Entrepreneurship and Innovation, 11 (1), 45-56, doi: 10.5367/000000010790772449

Anderson, M. H. (2008), 'Social networks and the cognitive motivation to realize network opportunities: A study of managers' information gathering behaviors', Journal of Organizational Behavior, 29 (1), 51-78, doi: 10.1002/job.459.

Arenius, P. and Minniti, M. (2005), 'Perceptual Variables and Nascent Entrepreneurship', Small Business Economics, 24 (3), 233-47, doi: 10.1007/s11187-005-1984-X.

Atherton, A. (2006), 'Should government be stimulating start-ups? An assessment of the scope for public intervention in new venture formation', Environment and Planning C: Government and Policy, 24 (1), 21-36, doi: 10.1068/c0436.

Audretsch, D. and Keilbach, M. (2004), 'Does entrepreneurship capital matter?', Entrepreneurship Theory and Practice, 28 (5), 419-29, doi: 10.1111/j.1540-6520.2004.00055.x.

Audretsch, D. B. and Keilbach, M. (2005), 'Entrepreneurship capital and regional growth', The Annals of Regional Science, 39, 457-469, doi: 10.1007/s00168-005-0246-9

Autio, E. and Acs, Z. (2010), 'Intellectual property protection and the formation of entrepreneurial growth aspirations'. Strategic Entrepreneurship Journal, 4 (3),234-251, doi:10.1002/sej.93.

Barney, J.B. (1991), 'Firm Resources and Sustained Competitive Advantage', Journal of Management, 17 (1), 99-120, doi: 10.1177/014920639101700108.

Barney, J.B., Wright, M., and Ketchen, D.J. (2001), 'The resource-based view of the firm: Ten years after 1991', Journal of Management, 27 (6), 625-41, doi: 10.1016/S0149-2063(01)00114-3.

Batjargal, B., et al. (2009), 'Women and men entrepreneurs' social networks and new venture performance across culture ', (Chicago: Academy of Management Proceedings), 1-6.

Beck, T., Demirguc-Kunt, A., and Levine, R. (2005), 'SMEs, growth, and poverty: cross-country evidence', Journal of Economic Growth, 10 (3), 199-229, doi: 10.1007/s10887-005-3533-5.

Becker, G.S. (1964), Human capital: A theoretical and empirical analysis, with special reference to education (New York: Columbia University Press).

Bergmann, H., and Stephan, U. (2013). Moving on from nascent entrepreneurship: Measuring crossnational differences in the transition to new business ownership. Small business economics, 41(4), 945-959.

Black, J., De Meza, D., and Jeffreys, D. (1996), 'House prices, the supply of collateral and the enterprise economy', The Economic Journal, 60-75, doi: 10.2307/2234931.

Blanchflower, D. G. and Oswald, A. J. (1998), 'What Makes an Entrepreneur?', Journal of Labor Economics, 16 (1), 26-60, doi: 10.1086/209881.

Blanchflower, D. G., Oswald, A. J., and Stutzer, A. (2001), 'Latent entrepreneurship across nations', European Economic Review, 45 (4-6), 680-91, doi: 10.1016/S0014-2921(01)00137-4.

Blanden, J., Gregg, P., and Machin, S. (2005), Intergenerational mobility in Europe and North America (London: Centre for Economic Performance). 
Bosworth, G. and Gray, D. (2012), 'The role of the private sector in regional economic recovery: The case of a middling district in Middle England', The International Journal of Entrepreneurship and Innovation, 13 (3), 201-10, doi:10.5367/ijei.2012.0082.

Brixy, U. (2014). The significance of entry and exit for regional productivity growth. Regional Studies, 48(6), 1051-1070.

Brush, C.G., Greene, P. G., and Hart, M. M. (2001), 'From Initial Idea to Unique Advantage: The Entrepreneurial Challenge of Constructing a Resource Base [and Executive Commentary]', The Academy of Management Executive (1993-2005), 15 (1), 64-80, doi: 10.1109/EMR.2002.1022409.

Bruton, G., Khavul, S., Siegel, D., and Wright, M. (2015). New Financial Alternatives in Seeding Entrepreneurship: Microfinance, Crowdfunding, and Peer-to-Peer Innovations. Entrepreneurship Theory and Practice, 39(1), 9-26.

Campos, C., Dent, A., Fry, R., and Reid, A. (2011), 'Impact of the Recession', Regional Trends, 43 $(10 / 11)$.

Carree, M. A. and Thurik, A. R. (2006), Handbook of Entrepreneurship Research (Cheltenham: Edward Elgar).

Carter, N., Brush, C., Greene, P., Gatewood, E. and Hart, M.(2003), 'Women entrepreneurs who break through to equity financing: the influence of human, social and financial capital', Venture 
Capital: an international journal of entrepreneurial finance, 5 (1), 1-28, doi: 10.1080/1369106032000082586.

Cassar, G. (2006), 'Entrepreneur opportunity costs and intended venture growth', Journal of Business Venturing, 21 (5), 610-32, doi: 10.1016/j.jbusvent.2005.02.011.

Chandler, G.N. and Hanks, S.H. (1998), 'An examination of the substitutability of founders human and financial capital in emerging business ventures', Journal of Business Venturing, 13 (5), 353-69, doi: 10.1016/S0883-9026(97)00034-7.

Coleman, S. (1988), 'Social capital in the creation of human capital', American Journal of Sociology, 95-120.

Cooke, P., Clifton, N., and Oleaga, M. (2005), 'Social capital, firm embeddedness and regional development', Regional Studies, 39 (8), 1065-77, doi: 10.1080/00343400500328065.

Cooper, A.C., Gimeno-Gascon, F.J., and Woo, C.Y. (1994), 'Initial human and financial capital as predictors of new venture performance', Journal of Business Venturing, 9 (5), 371-95, doi:10.1016/0883-9026(94)00022-M.

Davidsson, P. (1991), 'Continued entrepreneurship: Ability, need, and opportunity as determinants of small firm growth', Journal of Business Venturing, 6 (6), 405-29, doi: 10.1016/08839026(91)90028-C.

Davidsson, P. (2006), 'Nascent entrepreneurship: Empirical studies and developments', Foundations and Trends in Entrepreneurship, 2 (1), 1-76, doi: 10.1561/0300000005.

Davidsson, P. and Honig, B. (2003), 'The role of social and human capital among nascent entrepreneurs', Journal of Business Venturing, 18 (3), 301-31, doi: 10.1016/S08839026(02)00097-6.

DCLG (2010), The Indices of Multiple Deprivation 2007 (London: DCLG).

Dubini, P. and Aldrich, H. (1991), 'Personal and extended networks are central to the entrepreneurial process', Journal of Business Venturing, 6 (5), 305-13, doi: 10.1016/0883-9026(91)90021-5.

Dunn, T. and Holtz-Eakin, D. (2000), 'Financial capital, human capital, and the transition to selfemployment: Evidence from intergenerational links', Journal of Labor Economics, 18 (2), 282305, doi: $10.1086 / 209959$.

Ebben, J. and Johnson, A. (2006), 'Bootstrapping in small firms: An empirical analysis of change over time', Journal of Business Venturing, 21 (6), 851-65, doi:10.1016/j.jbusvent.2005.06.007.

Estrin, S., Korosteleva, J. and Mickiewicz, T. (2013), Which institutions encourage entrepreneurial growth aspirations?, Journal of Business Venturing, 28, 564-580, doi: 10.1016/j.jbusvent.2012.05.001.

Estrin, S., Mickiewicz, T. and Stephan, U. (2016). Human capital in social and commercial entrepreneurship. Journal of Business Venturing, 31(4), 449-467.

Evans, D.S. and Leighton, L.S. (1989), 'The determinants of changes in US self-employment, 19681987', Small Business Economics, 1 (2), 111-19, doi: 10.1007/BF00398629.

Evans, D.S. and Jovanovic, B. (1989), 'An Estimated Model of Entrepreneurial Choice under Liquidity Constraints', The Journal of Political Economy, 97 (4), 808-27.

Fairlie, R. W. (2004), Does business ownership provide a source of upward mobility for Blacks and Hispanics? (Cambridge, Mass: MIT Press).

Fairlie, R. W. and Krashinsky, H.A. (2012), 'Liquidity constraints, household wealth, and entrepreneurship revisited', Review of Income and Wealth, doi: 10.1111/j.14754991.2011.00491.x.

Foss, N. J. (2011). Why micro-foundations for resource-based theory are needed and what they may look like. Journal of Management, 37(5), 1413-1428.

Frankish, J. S., Roberts, R. G., Coad, A. and Storey, D. J. (2014). Is entrepreneurship a route out of deprivation?. Regional Studies, 48(6), 1090-1107.

Fraser, S. (2004), Finance for small and medium-sized enterprises. A Report of the 2004 UK Survey of SME Finances (Coventry: Warwick University ). 
Frese, M., Krauss, S. I., Keith, Nina, K., Escher, S., Grabarkiewicz, R., Luneng, S., Heers, C., Unger, J., and Friedrich, C. (2007), 'Business owners' action planning and its relationship to business 
success in three African countries', Journal of Applied Psychology, 92 (6), 1481, doi: 10.1037/0021-9010.92.6.1481.

Fritsch, M., and Storey, D. J. (2014). Entrepreneurship in a regional context: historical roots, recent developments and future challenges. Regional Studies, 48(6), 939-954.

Gartner, W.B. (2004), Handbook of Entrepreneurial Dynamics (Thousand Oaks: Sage).

Gelman, A. and Hill, J. (2006), Data analysis using regression and multilevel/hierarchical models (Cambridge University Press).

Granovetter, M. (1973), 'The strength of weak ties', American Journal of Sociology, 1360-80,

Greene, W. H. (2003), Econometric analysis (Pearson Education India).

Grilo, I. and Thurik, A. R. (2005), 'Latent and actual entrepreneurship in Europe and the US: some recent developments', International Entrepreneurship and Management Journal, 1 (4), 44159, doi: 10.1007/s11365-005-4772-9.

Grilo, I. and Thurik, A. (2006), 'Entrepreneurship in the old and new Europe', Entrepreneurship, Growth, and Innovation, 75-103, doi: 10.1007/0-387-32314-7_4.

Grilo, I. and Irigoyen, J. (2006), 'Entrepreneurship in the EU: To Wish and not to be', Small Business Economics, 26 (4), 305-18, doi: 10.1007/s11187-005-1561-3.

Grilo, I. and Thurik, R. (2008), 'Determinants of entrepreneurial engagement levels in Europe and the US', Industrial and Corporate Change, 17 (6), 1113-45, doi: 10.1093/icc/dtn044.

Hogwood, B. W. (1995). Regional administration in Britain since 1979: Trends and explanations. Regional \& Federal Studies, 5(3), 267-291.

Holtz-Eakin, D., Joulfaian, D. and Rosen, H.S. (1994), 'Entrepreneurial decisions and liquidity constraints', (National Bureau of Economic Research).

Hughes, M., Ireland, R. D. and Morgan, R. E. (2007), 'Stimulating dynamic value: Social capital and business incubation as a pathway to competitive success', Long Range Planning, 40 (2), 15477, doi: 10.1016/j.lrp.2007.03.008.

Hurst, E. and Lusardi, A. (2004), 'Liquidity constraints, household wealth, and entrepreneurship', Journal of Political Economy, 112 (2), 319-47, doi: 10.1086/381478.

Jayawarna, D., Rouse, J. and Kitching, J. (2011), 'Entrepreneur motivations and life course', International Small Business Journal, doi: 10.1177/0266242611401444.

Jonsson, S., and Lindbergh, J. (2013). The development of social capital and financing of entrepreneurial firms: From financial bootstrapping to bank funding. Entrepreneurship Theory and Practice, 37(4), 661-686.

Kalantaridis, C. and Bika, Z. (2006), 'Local embeddedness and rural entrepreneurship: case-study evidence from Cumbria, England', Environment and Planning A, 38 (8), 1561, doi: $10.1068 / a 3834$.

Kelley, D. J., Singer, S. and Herrington, M. (2011), 'The Global EntrepreneurshipMonitor 2010 Report.', Babson Park, MA: Babson College; UK, Global Entrepreneurship Research Association.

Kim, P. H., Aldrich, H. E. and Keister, L. A. (2006), 'Access (Not) Denied: The Impact of Financial, Human, and Cultural Capital on Entrepreneurial Entry in the United States', Small Business Economics, 27 (1), 5-22, doi: 10.1007/s11187-006-0007-x.

Kirzner, I. M. (1973), Competition and Entrepreneurship (Chicago: University of Chicago Press).

Klonek, F. E., Isidor, R. and Kauffeld, S. (2015). Different Stages of Entrepreneurship: Lessons from the Transtheoretical Model of Change. Journal of Change Management, 15(1), 43-63. doi: 10.1080/14697017.2014.918049

Klyver, K. and Schenkel, M. T. (2013). From resource access to use: Exploring the impact of resource combinations on nascent entrepreneurship. Journal of Small Business Management, 51(4), 539556.

Kor, Y. Y., Mahoney, J. T. and Michael, S. C. (2007). Resources, capabilities and entrepreneurial perceptions. Journal of Management Studies, 44(7), 1187-1212. 
Lee, R., Tüselmann, H., Jayawarna, D. and Rouse, J. (2011), 'Investigating the social capital and resource acquisition of entrepreneurs residing in deprived areas of England', Environment and Planning C: Government and Policy, 29 (6), 1054-72, doi: 10.1068/c1188b.

Levie, J. and Hart, M. (2010), 'Global entrepreneurship monitor: United Kingdom 2009 monitoring report', (London: Global Entrepreneurship Monitor Consortium).

Levie, J. and Hart, M. (2011), 'Global Entrepreneurship Monitor: 2011 United Kingdom Monitoring Report', (London: Global Entrepreneurship Monitor Consortium).

Long, J. S. and Freese, J. (2003), Regression models for categorical dependent variables using Stata (Texas: Stata Corporation).

MacDonald, R. (1996), 'Welfare dependency, the enterprise culture and self-employed survival', Work, Employment \& Society, 10 (3), 431-47, doi: 10.1177/0950017096103002.

Marlow, S. and Carter, S. (2004), 'Accounting for change: professional status, gender disadvantage and self-employment', Women in Management Review, 19 (1), 5-17, doi: $10.1108 / 09649420410518395$.

McKelvie, A. and Davidsson, P. (2009). 'From resource base to dynamic capabilites: an investigation of new firms', British Journal of Management, 20(S1), S63-S80, doi: 10.1111/j.14678551.2008.00613.x.

Miller, K.D. (2007), 'Risk and rationality in entrepreneurial processes', Strategic Entrepreneurship Journal, 1 (1-2), 57-74, doi: 10.1002/sej.2.

Minniti, M. and Lévesque, M. (2008), 'Recent developments in the economics of entrepreneurship', Journal of Business Venturing, 23 (6), 603-12, doi: 10.1016/j.jbusvent.2008.01.001.

ONS (2013), 'Region and Country Profiles, Key Statistics, available on http://webarchive.nationalarchives.gov.uk/20160105160709/http://ons.gov.uk/ons/publication s/re-reference-tables.html?edition=tcm\%3A77-316473 (accessed 23/04/2016)'.

Peteraf, M.A. (1993), 'The cornerstones of competitive advantage: A resource-based view', Strategic Management Journal, 14 (3), 179-91.

Peteraf, M.A. (2006), 'The cornerstones of competitive advantage: A resource-based view', Strategic Management Journal, 14 (3), 179-91, doi: 10.1002/smj.4250140303.

Reynolds, P., Bosma, N., Autio, E., Hunt, S., De Bono, N., et al. (2005), 'Global Entrepreneurship Monitor: Data Collection Design and Implementation 1998-2003', Small Business Economics, 24 (3), 205-31, doi: 10.1007/s11187-005-1980-1.

Rouse, J. and Kitching, J. (2006), 'Do enterprise support programmes leave women holding the baby?', Environment and Planning C: Government and Policy, 24 (1), 5-19, doi: $10.1068 / \mathrm{c} 0528$.

Rouse, J. and Jayawarna, D. (2006), 'The financing of disadvantaged entrepreneurs: Are enterprise programmes overcoming the finance gap?', International Journal of Entrepreneurial Behaviour \& Research, 12 (6), 388-400, doi: 10.1108/13552550610710162.

Schumpeter, J. (1934), 'The theory of economic development'. New Brunswick: Transaction Publishers. 
Shane, S. (2000), 'Prior Knowledge and the Discovery of Entrepreneurial Opportunities', Organization Science, 11 (4), 448-69, doi: 10.1287/orsc.11.4.448.14602.

Shane, S. (2003), A general theory of entrepreneurship: The individual-opportunity nexus (Northampton: Edward Elgar ).

Son, J. and Lin, N. (2008), 'Social capital and civic action: A network-based approach', Social Science Research, 37 (1), 330-49, doi: 10.1016/j.ssresearch.2006.12.004.

Sørensen, A. B. (2000), 'Toward a Sounder Basis for Class Analysis 1', American Journal of Sociology, 105 (6), 1523-58, doi: $10.1086 / 210463$.

Storey, D. (1994), Understanding the Small Business Sector (London: Routledge).

Storey, D. (2003), 'Entrepreneurship, small and medium sized enterprises and public policies', in Z. Acs and D. Audretsch (eds.), Handbook of Entrepreneurial Research (Boston.: Kluwer Academic).

Ucbasaran, D., Westhead, P. and Wright, M. (2008), 'Opportunity Identification and Pursuit: Does an Entrepreneur's Human Capital Matter?', Small Business Economics, 30 (2), 153-73, doi: 10.1007/s11187-006-9020-3.

Unger, J.M., Rauch, A., Frese, M. and Rosenbusch, N. (2011), 'Human capital and entrepreneurial success: A meta-analytical review', Journal of Business Venturing, 26 (3), 341-58, doi: 10.1016/j.jbusvent.2009.09.004.

Van der Zwan, P., Thurik, R. and Grilo, I. (2010), 'The entrepreneurial ladder and its determinants', Applied Economics, 42 (17), 2183-91, doi: 10.1080/00036840701765437.

Van der Zwan, P., Verheul, I., Thurik, R. and Grilo, I. (2013), 'Entrepreneurial Progress: Climbing the Entrepreneurial Ladder in Europe and the United States', Regional Studies, 47(5), 803-25, doi: 10.1080/00343404.2011.598504.

Van Stel, A. and Storey, D. (2004), 'The link between firm births and job creation: Is there a Upas tree effect?', Regional Studies, 38 (8), 893-909, doi: 10.1080/0034340042000280929.

Van Stel, A., Storey, D. J. and Thurik, A. R. (2007), 'The Effect of Business Regulations on Nascent and Young Business Entrepreneurship', Small Business Economics, 28 (2), 171-86, doi: 10.1007/s11187-006-9014-1.

Vivarelli, M. (2004), 'Are all the potential entrepreneurs so good?', Small Business Economics, 23 (1), 41-49, doi: 10.1023/B:SBEJ.0000026023.11752.a9.

Wasdani, K. P. and Mathew, M. (2014). Potential for opportunity recognition along the stages of entrepreneurship. Journal of Global Entrepreneurship Research, 4(1), 1.

Wernerfelt, B. (1984), 'A resource-based view of the firm', Strategic Management Journal, 5 (2), 17180, doi: $10.1002 / \mathrm{smj} .4250050207$.

Wernerfelt, B. (2007), 'The resource-based view of the firm: Ten years after', Strategic Management Journal, 16 (3), 171-74, doi: 10.1002/smj.4250160303.

Westhead, P., Ucbasaran, D. and Wright, M. (2005), 'Decisions, Actions, and Performance: Do Novice, Serial, and Portfolio Entrepreneurs Differ?*', Journal of Small Business Management, 43 (4), 393-417, doi: 10.1111/j.1540-627X.2005.00144.x.

Williams, N. and Williams, C. (2011), 'Tackling barriers to entrepreneurship in a deprived urban neighbourhood', Local Economy: The Journal of the Local Economy Policy Unit, 26 (1), 3042, doi: 10.1177/0269094210391166.

Wooldridge, J. M. (2010), Econometric analysis of cross section and panel data (MIT press).

Xavier, S.R., Kelley, D., Kew, J., Herrington, M. and Vorderwülbecke, A. (2012), The Global Entrepreneurship Monitor 2012 Report,' Babson Park, MA: Babson College; UK, Global Entrepreneurship Research Association.

\section{Tables}


Table 1: Total Entrepreneurial Activity in UK regions

\begin{tabular}{|l|r|r|r|}
\cline { 2 - 4 } \multicolumn{1}{c|}{} & 2007 & 2008 & 2009 \\
\hline Scotland & 4.6 & 4.5 & 3.6 \\
\hline North East & 4.6 & 5.1 & 4.9 \\
\hline North West & 5.3 & 5.5 & 4.9 \\
\hline N. Ireland & 4.9 & 4.6 & 5.2 \\
\hline West Midlands & 6.2 & 6.4 & 5.2 \\
\hline East Midlands & $\mathbf{5 . 3}$ & $\mathbf{5 . 3}$ & $\mathbf{5 . 3}$ \\
\hline South West & 6.5 & 5.9 & 5.8 \\
\hline Wales & 5.2 & 5.3 & 6 \\
\hline Yorks \& Humb & 4.7 & 4.2 & 6.1 \\
\hline South East & 5.3 & 5.5 & 6.2 \\
\hline East of England & 6.1 & 7.3 & 6.9 \\
\hline London & 6.2 & 5.6 & 7.4 \\
\hline United Kingdom & 5.5 & 5.5 & 5.8 \\
\hline
\end{tabular}

Source: GEM UK 2009

Table 2: Stages of entrepreneurial activity in UK regions

\begin{tabular}{|l|l|l|l|l|l|}
\cline { 2 - 6 } & $\begin{array}{l}\text { Expecting } \\
\text { to start a } \\
\text { business in } \\
\text { the next 3 } \\
\text { years }\end{array}$ & $\begin{array}{l}\text { Nascent } \\
\text { entrepreneurial } \\
\text { activity }\end{array}$ & $\begin{array}{l}\text { New business } \\
\text { owner/managers }\end{array}$ & TEA & $\begin{array}{l}\text { Established } \\
\text { business } \\
\text { owners }\end{array}$ \\
\hline East of England & 5.4 & 2.3 & 4.6 & 6.9 & 5.5 \\
\hline East Midlands & $\mathbf{5 . 8}$ & $\mathbf{2 . 4}$ & $\mathbf{3}$ & $\mathbf{5 . 3}$ & $\mathbf{4 . 8}$ \\
\hline London & 10.2 & 4.5 & 3.3 & 7.4 & 5.5 \\
\hline North East & 5 & 2.7 & 2.3 & 4.9 & 4.7 \\
\hline North West & 5.5 & 2.5 & 2.4 & 4.9 & 5.8 \\
\hline Northern Ireland & 5.1 & 2.9 & 2.5 & 5.2 & 6.4 \\
\hline Scotland & 4.3 & 1.1 & 2.6 & 3.6 & 4.8 \\
\hline South East & 6.2 & 3.1 & 3.2 & 6.2 & 6.4 \\
\hline South West & 5.3 & 1.4 & 4.5 & 5.8 & 8 \\
\hline Wales & 5.1 & 3.4 & 2.8 & 6 & 6 \\
\hline West Midlands & 6.4 & 2.8 & 2.4 & 5.2 & 5.1 \\
\hline $\begin{array}{l}\text { Yorkshire \& } \\
\text { Humberside }\end{array}$ & 6.6 & 3 & 3.3 & 6.1 & 6.7 \\
\hline United Kingdom & $\mathbf{6 . 2}$ & $\mathbf{2 . 7}$ & $\mathbf{3 . 2}$ & $\mathbf{5 . 8}$ & $\mathbf{5 . 8}$ \\
\hline
\end{tabular}

Source: GEM UK 2009 
Table 3: Variable Description

\begin{tabular}{|c|c|c|}
\hline Variable & Description & Percentage \\
\hline \multicolumn{3}{|l|}{ Dependent variable } \\
\hline Entrepreneurial Stages & $\begin{array}{l}\text { passive, no business ownership intention } \\
\text { considering } \\
\text { intending in the next three years } \\
\text { nascent (start-up) } \\
\text { new business owners ("baby businesses") }\end{array}$ & $\begin{array}{l}86.43 \\
5.19 \\
3.43 \\
2.29 \\
2.66 \\
\end{array}$ \\
\hline \multicolumn{3}{|l|}{ Individual resources and capabilities } \\
\hline Household income & $\begin{array}{l}\text { up to } £ 11500 \\
£ 11501-£ 20000 \\
£ 20001-£ 50000 \\
\text { over } £ 50000 \\
\text { not stated }\end{array}$ & $\begin{array}{l}22.97 \\
22.03 \\
23.01 \\
16.16 \\
15.83\end{array}$ \\
\hline Education & $\begin{array}{l}\text { No formal qualifications } \\
\text { GCSE } \\
\text { A level } \\
\text { Vocational and other } \\
\text { Batchelor } \\
\text { Masters } \\
\text { Doctorate }\end{array}$ & $\begin{array}{c}14.26 \\
27.42 \\
19.45 \\
12.34 \\
19.55 \\
6.06 \\
0.93\end{array}$ \\
\hline Employment status & $\begin{array}{l}1=\text { the respondent is employed } \\
0=\text { not in employment }\end{array}$ & $\begin{array}{l}74.3 \\
25.7\end{array}$ \\
\hline $\begin{array}{l}\text { Knowledge and skills ("have the knowledge, skill and } \\
\text { experience required to start a business") }\end{array}$ & $\begin{array}{l}1=\text { yes } \\
0=\text { no }\end{array}$ & $\begin{array}{l}31.9 \\
68.1\end{array}$ \\
\hline $\begin{array}{l}\text { Knowing other entrepreneurs (personally knows someone } \\
\text { who has started a business in the previous } 2 \text { y) }\end{array}$ & $\begin{array}{l}1=\text { yes } \\
0=\text { no }\end{array}$ & $\begin{array}{l}14.8 \\
85.2\end{array}$ \\
\hline Business angel (in past 3 years) & $\begin{array}{l}1=\text { yes } \\
0=\text { no }\end{array}$ & $\begin{array}{l}12.0 \\
88.0\end{array}$ \\
\hline $\begin{array}{l}\text { Business Owners (established business owners with over } \\
42 \text { months old) }\end{array}$ & $\begin{array}{l}1=\text { yes } \\
0=\text { no }\end{array}$ & $\begin{array}{l}6.0 \\
94.0 \\
\end{array}$ \\
\hline Age of respondent & $\begin{array}{l}18 \text { to } 24 \\
25 \text { to } 34 \\
35 \text { to } 44 \\
45 \text { to } 55 \\
55 \text { to } 64\end{array}$ & $\begin{array}{l}6.2 \\
15.37 \\
25.70 \\
26.11 \\
26.62 \\
\end{array}$ \\
\hline Gender: Male & $\begin{array}{l}0=\text { female } \\
1=\text { male }\end{array}$ & $\begin{array}{l}59.4 \\
40.6\end{array}$ \\
\hline \multicolumn{3}{|l|}{ Environmental variables } \\
\hline Share of business owners & $\begin{array}{l}\text { Owners-managers of businesses over } 42 \\
\text { months old (prevalence rate in LSOA) }\end{array}$ & $\begin{array}{l}\text { Mean } 0.06 \\
\text { SD } \quad 12.98)\end{array}$ \\
\hline IMD & $\begin{array}{l}\text { Index of Multiple Deprivation categorised } \\
\text { into } 10 \text { even quintiles based on the } \\
\text { quantile function }\end{array}$ & \\
\hline Urban & $\begin{array}{l}1=\text { urban } \\
0=\text { rural }\end{array}$ & $\begin{array}{l}67.3 \\
32.7\end{array}$ \\
\hline (East Midlands') County & $\begin{array}{l}\text { Derby } \\
\text { Derbyshire } \\
\text { Leicester } \\
\text { Leicestershire } \\
\text { Lincolnshire } \\
\text { Northamptonshire } \\
\text { Nottingham } \\
\text { Nottinghamshire } \\
\text { Rutland }\end{array}$ & $\begin{array}{l}4.57 \\
18.82 \\
5.49 \\
15.76 \\
17.17 \\
14.62 \\
4.73 \\
18.02 \\
0.82 \\
\end{array}$ \\
\hline
\end{tabular}


Table 4: Correlations: Spearman rho correlation coefficients for individual level variables and community characteristics

\begin{tabular}{|c|c|c|c|c|c|c|c|c|c|c|c|c|c|c|c|}
\hline & Min & Max & 0 & 1 & 2 & 3 & 4 & 5 & 6 & 7 & 8 & 9 & 10 & 11 & 12 \\
\hline 0 Entrepreneurial stages & & & 1 & & & & & & & & & & & & \\
\hline 1 Income & 1 & 5 & 0.01 & 1 & & & & & & & & & & & \\
\hline 2 Education & 1 & 7 & 0.12 & 0.18 & 1 & & & & & & & & & & \\
\hline 3 Employment Status & 0 & 1 & 0.05 & 0.12 & 0.16 & 1 & & & & & & & & & \\
\hline 4 Knowledge and skills & 0 & 1 & 0.37 & 0.08 & 0.12 & 0.13 & 1 & & & & & & & & \\
\hline 5 Knowing other entrepreneurs & 0 & 1 & 0.32 & 0.06 & 0.13 & 0.09 & 0.35 & 1 & & & & & & & \\
\hline 6 Business angel & 0 & 1 & 0.09 & 0.03 & 0.03 & 0.31 & 0.12 & 0.16 & 1 & & & & & & \\
\hline 7 Business owners & 0 & 1 & -0.10 & 0.07 & 0.00 & 0.13 & 0.30 & 0.12 & 0.07 & 1 & & & & & \\
\hline 8 Share of business owners & 0 & 1 & -0.03 & 0.07 & 0.02 & 0.07 & 0.17 & 0.07 & 0.03 & 0.49 & 1 & & & & \\
\hline 9 Age & 0 & 1 & -0.15 & -0.04 & -0.17 & -0.15 & -0.01 & -0.11 & 0.01 & 0.09 & 0.06 & 1 & & & \\
\hline 10 Gender: Male & 1 & 5 & 0.13 & 0.01 & 0.05 & 0.10 & 0.19 & 0.11 & 0.04 & 0.12 & 0.04 & 0.03 & 1 & & \\
\hline 11 IMD & 0 & 1 & -0.01 & -0.19 & -0.18 & -0.10 & -0.08 & -0.04 & -0.02 & -0.06 & -0.16 & -0.08 & -0.00 & 1 & \\
\hline 12 Urban & 1 & 9 & -0.02 & -0.08 & -0.04 & -0.01 & -0.06 & -0.01 & -0.01 & -0.06 & -0.15 & -0.07 & 0.03 & 0.27 & 1 \\
\hline
\end{tabular}


Table 5: Multinomial logit estimates. Model 1

\begin{tabular}{|c|c|c|c|}
\hline \multicolumn{4}{|l|}{ EXPLANATORY VARIABLES } \\
\hline \multicolumn{4}{|l|}{ EXPLANATORY VARIABLES } \\
\hline Income: $£ 11,501-£ 20,000$ & $\begin{array}{l}0.762 \\
(0.129)\end{array}$ & $\begin{array}{l}0.614^{*} \\
(0.127)\end{array}$ & $\begin{array}{l}0.655+ \\
(0.157)\end{array}$ \\
\hline Income: $£ 20,001-£ 50,000$ & $\begin{array}{l}0.884 \\
(0.151)\end{array}$ & $\begin{array}{l}0.686+ \\
(0.142)\end{array}$ & $\begin{array}{l}0.436 * * * \\
(0.109)\end{array}$ \\
\hline Income: over $£ 50,000$ & $\begin{array}{l}0.666^{*} \\
(0.127)\end{array}$ & $\begin{array}{l}0.559^{*} \\
(0.134)\end{array}$ & $\begin{array}{l}0.311 * * * \\
(0.089)\end{array}$ \\
\hline Income: not stated & $\begin{array}{l}0.647 * \\
(0.128)\end{array}$ & $\begin{array}{l}0.432 * * \\
(0.115)\end{array}$ & $\begin{array}{l}0.543 * \\
(0.161)\end{array}$ \\
\hline Education: GCSE & $\begin{array}{l}1.725^{*} \\
(0.424)\end{array}$ & $\begin{array}{l}1.655 \\
(0.599)\end{array}$ & $\begin{array}{l}0.561+ \\
(0.166)\end{array}$ \\
\hline Education: A level & $\begin{array}{l}2.323 * * * \\
(0.586)\end{array}$ & $\begin{array}{l}3.205^{* *} \\
(1.157)\end{array}$ & $\begin{array}{l}0.929 \\
(0.273)\end{array}$ \\
\hline Education: vocational and others & $\begin{array}{l}1.559+ \\
(0.420)\end{array}$ & $\begin{array}{l}2.309 * \\
(0.873)\end{array}$ & $\begin{array}{l}0.715 \\
(0.238)\end{array}$ \\
\hline Education: bachelor & $\begin{array}{l}2.751 * * * \\
(0.689)\end{array}$ & $\begin{array}{l}3.311 * * * \\
(1.188)\end{array}$ & $\begin{array}{l}0.940 \\
(0.302)\end{array}$ \\
\hline Education: masters & $\begin{array}{l}1.957^{*} \\
(0.599)\end{array}$ & $\begin{array}{l}2.213+ \\
(0.969)\end{array}$ & $\begin{array}{l}1.229 \\
(0.429)\end{array}$ \\
\hline Education: doctorate & $\begin{array}{l}3.058^{*} \\
(1.551)\end{array}$ & $\begin{array}{l}6.995 * * * \\
(4.049)\end{array}$ & $\begin{array}{l}1.091 \\
(0.959)\end{array}$ \\
\hline Employment status & $\begin{array}{l}0.745^{*} \\
(0.107)\end{array}$ & $\begin{array}{l}0.580 * * \\
(0.099)\end{array}$ & $\begin{array}{l}1.257 \\
(0.308)\end{array}$ \\
\hline Knowledge and skills & $\begin{array}{l}5.568 * * * \\
(0.640)\end{array}$ & $\begin{array}{l}6.793 * * * \\
(1.042)\end{array}$ & $\begin{array}{l}16.726^{* * *} \\
(3.895)\end{array}$ \\
\hline Owners of new businesses & $\begin{array}{l}0.000 * * * \\
(0.000)\end{array}$ & $\begin{array}{l}0.000 * * * \\
(0.000)\end{array}$ & $\begin{array}{l}0.000 * * * \\
(0.000)\end{array}$ \\
\hline Knowing other entrepreneurs & $\begin{array}{l}2.414 * * * \\
(0.310)\end{array}$ & $\begin{array}{l}4.413 * * * \\
(0.666)\end{array}$ & $\begin{array}{l}4.350 * * * \\
(0.784)\end{array}$ \\
\hline Business angel & $\begin{array}{l}1.293 \\
(0.555)\end{array}$ & $\begin{array}{l}2.693^{* *} \\
(0.969)\end{array}$ & $\begin{array}{l}1.378 \\
(0.726)\end{array}$ \\
\hline Business owners & $\begin{array}{l}0.000 * * * \\
(0.000)\end{array}$ & $\begin{array}{l}0.000 * * * \\
(0.000)\end{array}$ & $\begin{array}{l}0.000 * * * \\
(0.000)\end{array}$ \\
\hline Share of business owners & $\begin{array}{l}3.183^{*} \\
(1.522)\end{array}$ & $\begin{array}{l}2.193 \\
(1.456)\end{array}$ & $\begin{array}{l}3.229 \\
(2.622)\end{array}$ \\
\hline Age: 25 to 34 & $\begin{array}{l}0.621 * \\
(0.126)\end{array}$ & $\begin{array}{l}0.607 * \\
(0.142)\end{array}$ & $\begin{array}{l}1.360 \\
(0.544)\end{array}$ \\
\hline Age: 35 to 44 & $\begin{array}{l}0.453 * * * \\
(0.087)\end{array}$ & $\begin{array}{l}0.539 * * \\
(0.119)\end{array}$ & $\begin{array}{l}1.139 \\
(0.427)\end{array}$ \\
\hline Age: 45 to 55 & $\begin{array}{l}0.343 \text { *** } \\
(0.068)\end{array}$ & $\begin{array}{l}0.403 * * * \\
(0.094)\end{array}$ & $\begin{array}{l}0.748 \\
(0.293)\end{array}$ \\
\hline Age: 55 to 64 & $\begin{array}{l}0.205 * * * \\
(0.046)\end{array}$ & $\begin{array}{l}0.168 * * * \\
(0.047)\end{array}$ & $\begin{array}{l}0.479+ \\
(0.200)\end{array}$ \\
\hline Gender: Male & $\begin{array}{l}1.915^{* * *} \\
(0.211)\end{array}$ & $\begin{array}{l}1.625 * * * \\
(0.221)\end{array}$ & $\begin{array}{l}1.276 \\
(0.209)\end{array}$ \\
\hline
\end{tabular}

Table 5 continued 


\begin{tabular}{|c|c|c|c|}
\hline IMD: Quintle 2 & $\begin{array}{l}0.913 \\
(0.206)\end{array}$ & $\begin{array}{l}1.147 \\
(0.303)\end{array}$ & $\begin{array}{l}1.840+ \\
(0.669)\end{array}$ \\
\hline IMD: Quintle 3 & $\begin{array}{l}0.938 \\
(0.222)\end{array}$ & $\begin{array}{l}1.209 \\
(0.328)\end{array}$ & $\begin{array}{l}1.799 \\
(0.653)\end{array}$ \\
\hline IMD: Quintle 4 & $\begin{array}{l}0.999 \\
(0.228)\end{array}$ & $\begin{array}{l}0.963 \\
(0.278)\end{array}$ & $\begin{array}{l}1.640 \\
(0.618)\end{array}$ \\
\hline IMD: Quintle 5 & $\begin{array}{l}0.935 \\
(0.222)\end{array}$ & $\begin{array}{l}0.845 \\
(0.259)\end{array}$ & $\begin{array}{l}1.192 \\
(0.510)\end{array}$ \\
\hline IMD: Quintle 6 & $\begin{array}{l}1.220 \\
(0.285)\end{array}$ & $\begin{array}{l}1.073 \\
(0.328)\end{array}$ & $\begin{array}{l}2.072 * \\
(0.766)\end{array}$ \\
\hline IMD: Quintle 7 & $\begin{array}{l}1.099 \\
(0.264)\end{array}$ & $\begin{array}{l}0.778 \\
(0.251)\end{array}$ & $\begin{array}{l}1.448 \\
(0.632)\end{array}$ \\
\hline IMD: Quintle 8 & $\begin{array}{l}1.333 \\
(0.327)\end{array}$ & $\begin{array}{l}0.800 \\
(0.261)\end{array}$ & $\begin{array}{l}1.095 \\
(0.474)\end{array}$ \\
\hline IMD: Quintle 9 & $\begin{array}{l}1.216 \\
(0.317)\end{array}$ & $\begin{array}{l}1.058 \\
(0.372)\end{array}$ & $\begin{array}{l}2.596^{*} \\
(1.102)\end{array}$ \\
\hline IMD: Quintle 10 & $\begin{array}{l}1.371 \\
(0.415)\end{array}$ & $\begin{array}{l}0.636 \\
(0.252)\end{array}$ & $\begin{array}{l}0.758 \\
(0.428)\end{array}$ \\
\hline Urban & $\begin{array}{l}0.911 \\
(0.119)\end{array}$ & $\begin{array}{l}1.015 \\
(0.159)\end{array}$ & $\begin{array}{l}0.753 \\
(0.139)\end{array}$ \\
\hline County: Derbyshire & $\begin{array}{l}1.367+ \\
(0.251)\end{array}$ & $\begin{array}{l}1.035 \\
(0.255)\end{array}$ & $\begin{array}{l}0.597+ \\
(0.158)\end{array}$ \\
\hline County: Leicester & $\begin{array}{l}1.383+ \\
(0.262)\end{array}$ & $\begin{array}{l}1.701 * \\
(0.388)\end{array}$ & $\begin{array}{l}1.156 \\
(0.287)\end{array}$ \\
\hline County: Leicestershire & $\begin{array}{l}1.464^{*} \\
(0.284)\end{array}$ & $\begin{array}{l}1.312 \\
(0.336)\end{array}$ & $\begin{array}{l}0.804 \\
(0.232)\end{array}$ \\
\hline County: Lincolnshire & $\begin{array}{l}1.241 \\
(0.262)\end{array}$ & $\begin{array}{l}1.419 \\
(0.342)\end{array}$ & $\begin{array}{l}0.604+ \\
(0.173)\end{array}$ \\
\hline County: Northamptonshire & $\begin{array}{l}1.485 \\
(0.406)\end{array}$ & $\begin{array}{l}1.692 \\
(0.601)\end{array}$ & $\begin{array}{l}1.373 \\
(0.483)\end{array}$ \\
\hline County: Nottingham & $\begin{array}{l}1.842^{*} \\
(0.518)\end{array}$ & $\begin{array}{l}3.648 * * * \\
(1.176)\end{array}$ & $\begin{array}{l}1.458 \\
(0.584)\end{array}$ \\
\hline County: Nottinghamshire & $\begin{array}{l}1.391 \\
(0.378)\end{array}$ & $\begin{array}{l}1.826 \\
(0.728)\end{array}$ & $\begin{array}{l}0.657 \\
(0.364)\end{array}$ \\
\hline County: Ruthland & $\begin{array}{l}2.484 * \\
(1.029)\end{array}$ & $\begin{array}{l}2.919 * \\
(1.440)\end{array}$ & $\begin{array}{l}1.150 \\
(0.792)\end{array}$ \\
\hline Constant & $\begin{array}{l}0.027 * * * \\
(0.011)\end{array}$ & $\begin{array}{l}0.014 * * * \\
(0.007)\end{array}$ & $\begin{array}{l}0.006 \text { *** } \\
(0.004)\end{array}$ \\
\hline Observations & 8,269 & 8,269 & 8,269 \\
\hline Log Likelihood & -2939.816 & -2939.816 & -2939.816 \\
\hline$D F$ & 120.000 & 120.000 & 120.000 \\
\hline Wald's chi2 & 64846.316 & 64846.316 & 64846.316 \\
\hline Pseudo R--squared & 0.225 & 0.225 & 0.225 \\
\hline
\end{tabular}

Note: + significant at $10 \% * 5 \%, * * 1 \%, * * * .01 \%$. Clustered standard errors in parentheses 
Table 6: Multinomial logit estimates. Model 2

\begin{tabular}{|c|c|c|c|}
\hline & $\begin{array}{l}\text { Considering } \\
\text { \&Intentions }\end{array}$ & Nascent & $\begin{array}{l}\text { Baby } \\
\text { businesses }\end{array}$ \\
\hline \multicolumn{4}{|l|}{ EXPLANATORY VARIABLES } \\
\hline Education: GCSE & $\begin{array}{l}2.030 * * * \\
(0.411)\end{array}$ & $\begin{array}{l}0.817 \\
(0.231)\end{array}$ & $\begin{array}{l}1.948 * \\
(0.649)\end{array}$ \\
\hline Education: A level & $\begin{array}{l}3.263 * * * \\
(0.673)\end{array}$ & $\begin{array}{l}1.315 \\
(0.379)\end{array}$ & $\begin{array}{l}2.319 * \\
(0.807)\end{array}$ \\
\hline Education: vocational and others & $\begin{array}{l}2.525 * * * \\
(0.548)\end{array}$ & $\begin{array}{l}1.198 \\
(0.369)\end{array}$ & $\begin{array}{l}2.210^{*} \\
(0.798)\end{array}$ \\
\hline Education: bachelor & $\begin{array}{l}3.705^{* * *} \\
(0.745)\end{array}$ & $\begin{array}{l}1.354 \\
(0.403)\end{array}$ & $\begin{array}{l}2.732 * * \\
(0.936)\end{array}$ \\
\hline Education: masters & $\begin{array}{l}2.798 * * * \\
(0.688)\end{array}$ & $\begin{array}{l}1.793+ \\
(0.607)\end{array}$ & $\begin{array}{l}4.016 * * * \\
(1.486)\end{array}$ \\
\hline Education: doctorate & $\begin{array}{l}5.468 * * * \\
(2.066)\end{array}$ & $\begin{array}{l}1.490 \\
(1.172)\end{array}$ & $\begin{array}{l}4.864 * * \\
(2.785)\end{array}$ \\
\hline Business angel & $\begin{array}{l}5.506 * * * \\
(1.490)\end{array}$ & $\begin{array}{l}5.581 * * * \\
(2.687)\end{array}$ & $\begin{array}{l}9.881 * * * \\
(3.446)\end{array}$ \\
\hline Businesses owners & $\begin{array}{l}0.000 * * * \\
(0.000)\end{array}$ & $\begin{array}{l}0.000 * * * \\
(0.000)\end{array}$ & $\begin{array}{l}0.053 * * * \\
(0.043)\end{array}$ \\
\hline Share of business owners & $\begin{array}{l}2.280 * \\
(0.871)\end{array}$ & $\begin{array}{l}2.023 \\
(1.470)\end{array}$ & $\begin{array}{l}1.865 \\
(1.300)\end{array}$ \\
\hline Age: 25 to 34 & $\begin{array}{l}0.754+ \\
(0.112)\end{array}$ & $\begin{array}{l}1.964+ \\
(0.721)\end{array}$ & $\begin{array}{l}3.096^{*} \\
(1.390)\end{array}$ \\
\hline Age: 35 to 44 & $\begin{array}{l}0.581 * * * \\
(0.080)\end{array}$ & $\begin{array}{l}1.546 \\
(0.522)\end{array}$ & $\begin{array}{l}3.645^{* *} \\
(1.595)\end{array}$ \\
\hline Age: 45 to 55 & $\begin{array}{l}0.417 * * * \\
(0.061)\end{array}$ & $\begin{array}{l}1.024 \\
(0.364)\end{array}$ & $\begin{array}{l}1.824 \\
(0.821)\end{array}$ \\
\hline Age: 55 to 64 & $\begin{array}{l}0.236 * * * \\
(0.041)\end{array}$ & $\begin{array}{l}0.631 \\
(0.244)\end{array}$ & $\begin{array}{l}1.413 \\
(0.652)\end{array}$ \\
\hline Gender: Male & $\begin{array}{l}2.274 * * * \\
(0.189)\end{array}$ & $\begin{array}{l}1.855^{* * * *} \\
(0.297)\end{array}$ & $\begin{array}{l}3.496 * * * \\
(0.501)\end{array}$ \\
\hline IMD: Quintle 2 & $\begin{array}{l}1.025 \\
(0.175)\end{array}$ & $\begin{array}{l}1.963+ \\
(0.707)\end{array}$ & $\begin{array}{l}1.259 \\
(0.329)\end{array}$ \\
\hline IMD: Quintle 3 & $\begin{array}{l}1.066 \\
(0.195)\end{array}$ & $\begin{array}{l}2.023 * \\
(0.718)\end{array}$ & $\begin{array}{l}1.728 * \\
(0.443)\end{array}$ \\
\hline IMD: Quintle 4 & $\begin{array}{l}0.977 \\
(0.175)\end{array}$ & $\begin{array}{l}1.696 \\
(0.611)\end{array}$ & $\begin{array}{l}1.288 \\
(0.346)\end{array}$ \\
\hline IMD: Quintle 5 & $\begin{array}{l}0.980 \\
(0.177)\end{array}$ & $\begin{array}{l}1.450 \\
(0.585)\end{array}$ & $\begin{array}{l}1.157 \\
(0.333)\end{array}$ \\
\hline IMD: Quintle 6 & $\begin{array}{l}1.124 \\
(0.210)\end{array}$ & $\begin{array}{l}2.096^{*} \\
(0.759)\end{array}$ & $\begin{array}{l}0.845 \\
(0.293)\end{array}$ \\
\hline IMD: Quintle 7 & $\begin{array}{l}0.887 \\
(0.171)\end{array}$ & $\begin{array}{l}1.343 \\
(0.531)\end{array}$ & $\begin{array}{l}0.451+ \\
(0.186)\end{array}$ \\
\hline
\end{tabular}


Table 6 continued

\begin{tabular}{|c|c|c|c|}
\hline IMD: Quintle 8 & $\begin{array}{l}1.150 \\
(0.215)\end{array}$ & $\begin{array}{l}1.371 \\
(0.558)\end{array}$ & $\begin{array}{l}1.223 \\
(0.394)\end{array}$ \\
\hline IMD: Quintle 9 & $\begin{array}{l}1.125 \\
(0.238)\end{array}$ & $\begin{array}{l}2.684 * \\
(1.124)\end{array}$ & $\begin{array}{l}1.104 \\
(0.404)\end{array}$ \\
\hline IMD: Quintle 10 & $\begin{array}{l}1.106 \\
(0.254)\end{array}$ & $\begin{array}{l}0.878 \\
(0.455)\end{array}$ & $\begin{array}{l}1.003 \\
(0.452)\end{array}$ \\
\hline Urban & $\begin{array}{l}0.914 \\
(0.091)\end{array}$ & $\begin{array}{l}0.777 \\
(0.140)\end{array}$ & $\begin{array}{l}0.658^{* *} \\
(0.103)\end{array}$ \\
\hline County: Derbyshire & $\begin{array}{l}1.275+ \\
(0.182)\end{array}$ & $\begin{array}{l}0.613+ \\
(0.159)\end{array}$ & $\begin{array}{l}1.041 \\
(0.245)\end{array}$ \\
\hline County: Leicester & $\begin{array}{l}1.447 * \\
(0.208)\end{array}$ & $\begin{array}{l}1.077 \\
(0.266)\end{array}$ & $\begin{array}{l}0.971 \\
(0.237)\end{array}$ \\
\hline County: Leicestershire & $\begin{array}{l}1.357^{*} \\
(0.206)\end{array}$ & $\begin{array}{l}0.755 \\
(0.205)\end{array}$ & $\begin{array}{l}1.007 \\
(0.243)\end{array}$ \\
\hline County: Lincolnshire & $\begin{array}{l}1.350+ \\
(0.219)\end{array}$ & $\begin{array}{l}0.581+ \\
(0.162)\end{array}$ & $\begin{array}{l}1.280 \\
(0.295)\end{array}$ \\
\hline County: Northamptonshire & $\begin{array}{l}1.549 * \\
(0.328)\end{array}$ & $\begin{array}{l}1.205 \\
(0.384)\end{array}$ & $\begin{array}{l}1.152 \\
(0.515)\end{array}$ \\
\hline County: Nottingham & $\begin{array}{l}2.120 * * * \\
(0.424)\end{array}$ & $\begin{array}{l}1.120 \\
(0.406)\end{array}$ & $\begin{array}{l}1.398 \\
(0.560)\end{array}$ \\
\hline County: Nottinghamshire & $\begin{array}{l}1.466+ \\
(0.335)\end{array}$ & $\begin{array}{l}0.592 \\
(0.302)\end{array}$ & $\begin{array}{l}1.117 \\
(0.446)\end{array}$ \\
\hline County: Ruthland & $\begin{array}{l}2.461 * * \\
(0.792)\end{array}$ & $\begin{array}{l}0.993 \\
(0.632)\end{array}$ & $\begin{array}{l}1.251 \\
(0.798)\end{array}$ \\
\hline Constant & $\begin{array}{l}0.041 * * * \\
(0.012)\end{array}$ & $\begin{array}{l}0.013 * * * \\
(0.007)\end{array}$ & $\begin{array}{l}0.003 * * * \\
(0.002)\end{array}$ \\
\hline Observations & 8,269 & 8,269 & 8,269 \\
\hline Log Likelihood & -3906.661 & -3906.661 & -3906.661 \\
\hline$D F$ & 96.000 & 96.000 & 96.000 \\
\hline Wald's chi2 & 39791.058 & 39791.058 & 39791.058 \\
\hline Pseudo R--squared & 0.092 & 0.092 & 0.092 \\
\hline
\end{tabular}

Note: + significant at $10 \% * 5 \%, * * 1 \%, * * * .01 \%$. Clustered standard errors in parentheses 


\section{Figures}

Figure 1: Predictive margins of education for owners-managers of new firms (baby businesses)

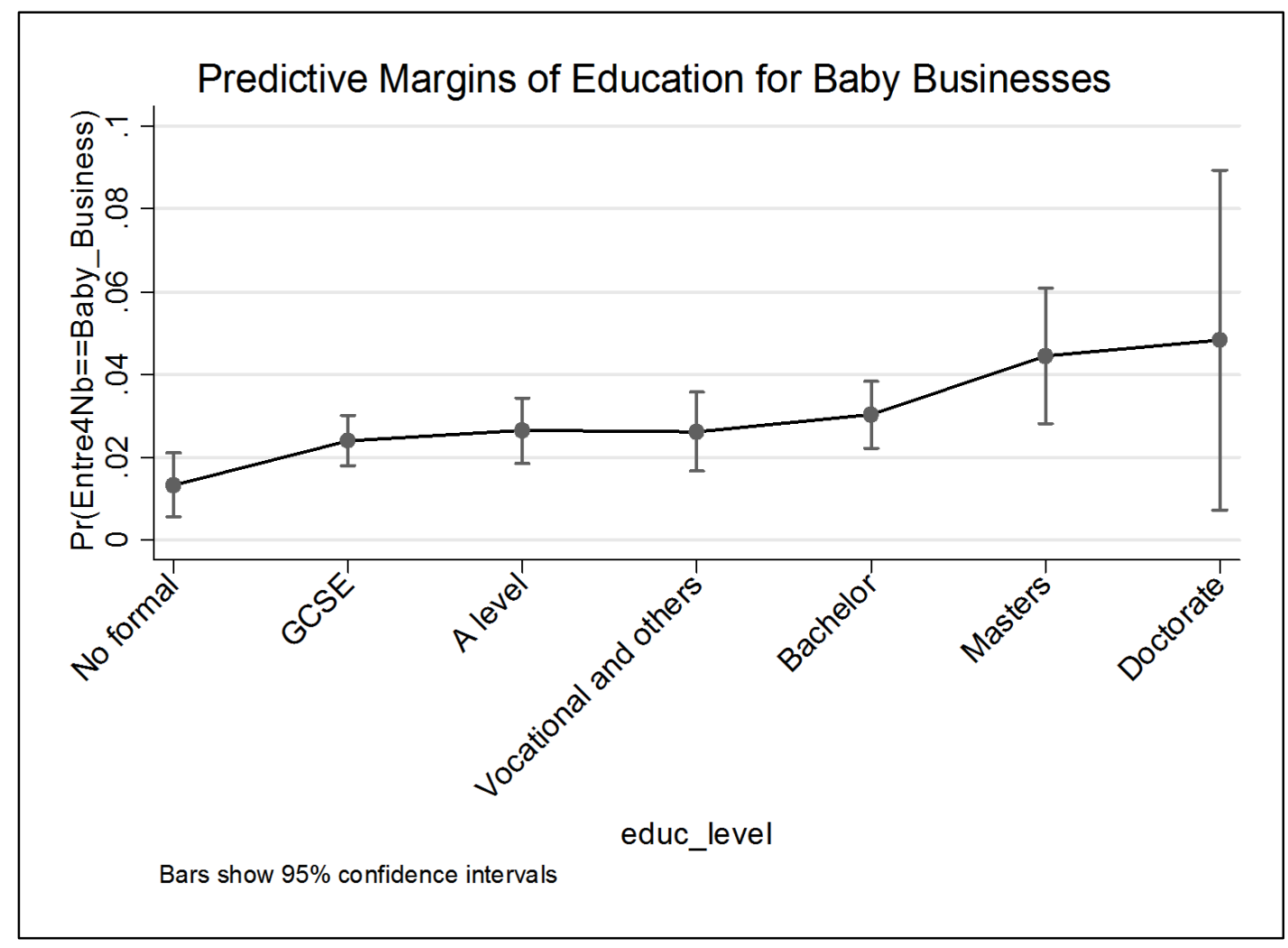

Figure 2: Predictive margins of education for nascent entrepreneurs (start-ups) 


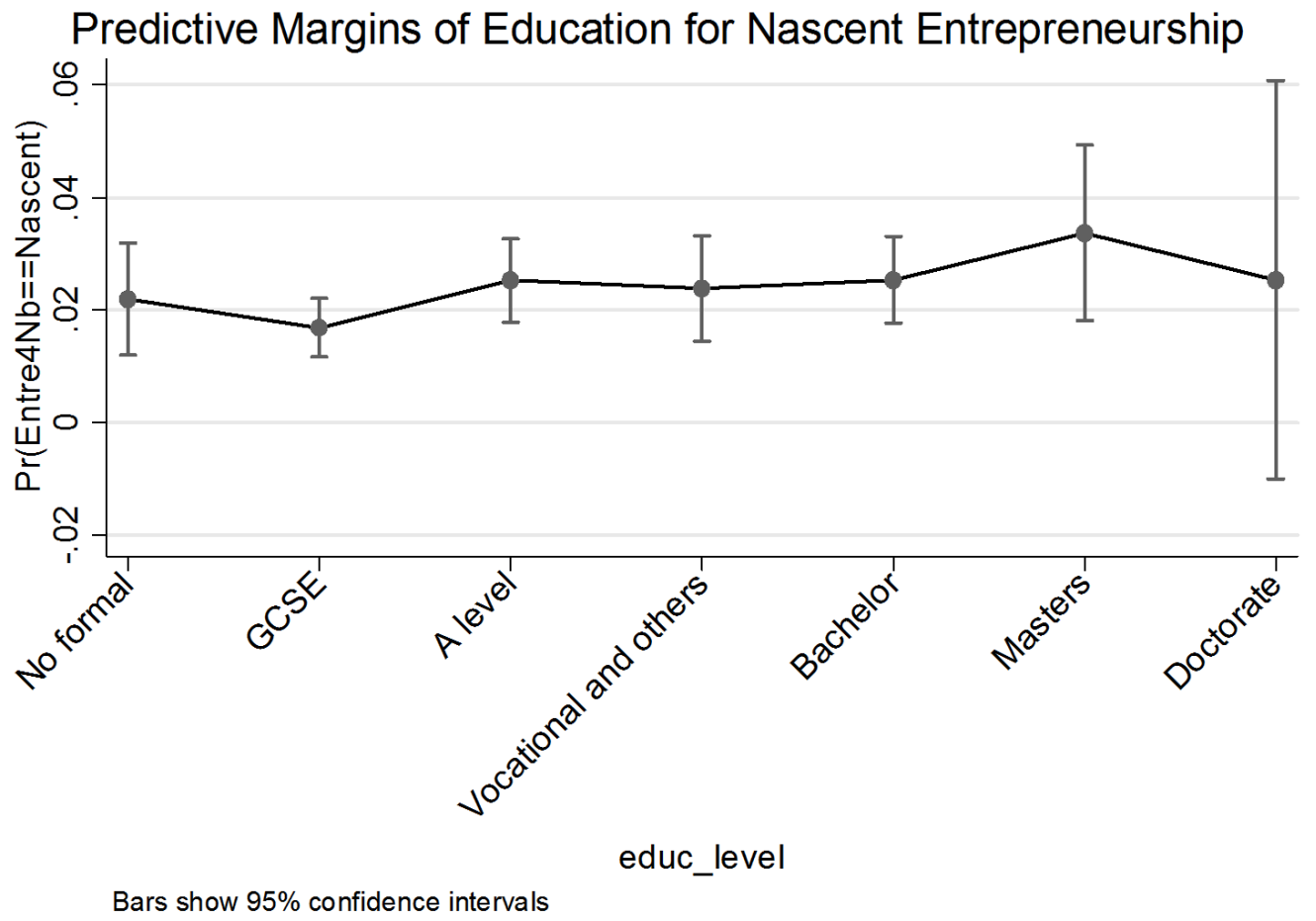

Figure 3: Factor changes in odds of entrepreneurial stages, household income categories, being in employment and knowledge and skills

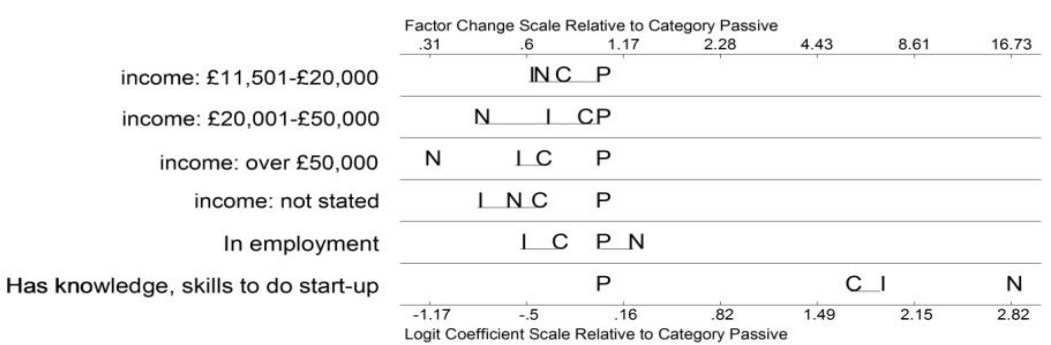


Figure 4: Factor changes in odds of entrepreneurial stages, age.

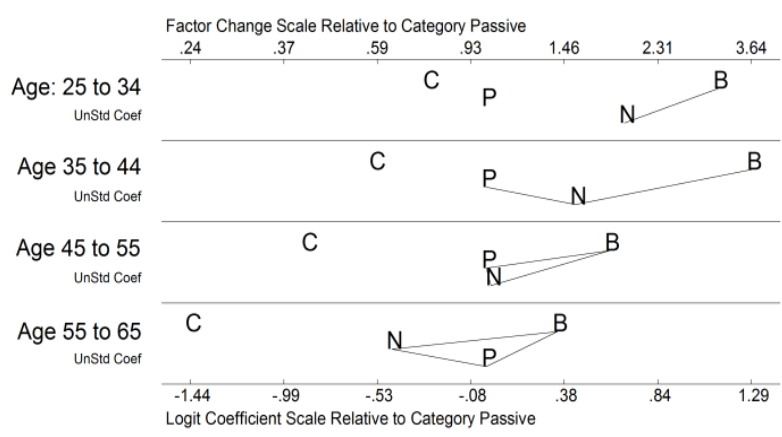

Figure 5: Factor changes in odds of entrepreneurial stages. gender, business owners, business angel and urban area.

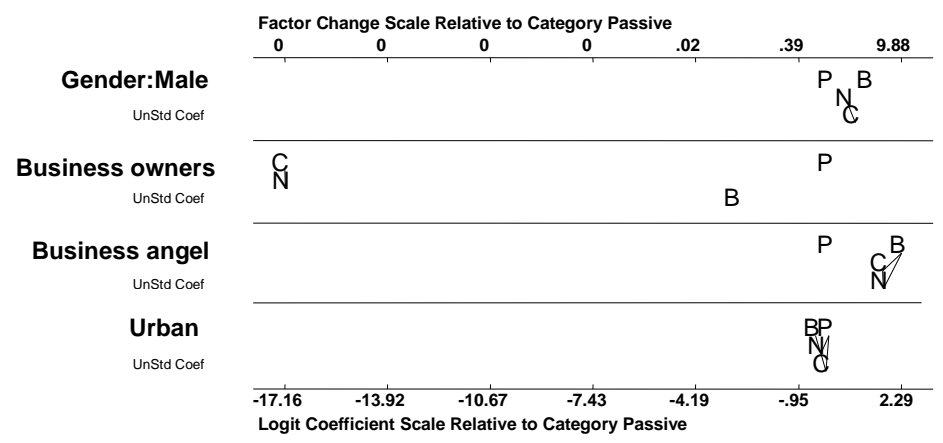

